\title{
Reexamining Stock Valuation and Inflation: The Implications of Analysts' Earnings Forecasts
}

\author{
Steven A. Sharpe \\ Division of Research and Statistics \\ Federal Reserve Board \\ Washington, D.C. 20551 \\ (202) $452-2875$ \\ (202)452-3819 (fax) \\ ssharpe@frb.gov
}

July 2001

(Forthcoming, The Review of Economics and Statistics)

The views expressed herein are those of the author and do not necessarily reflect the views of the Board nor the staff of the Federal Reserve System. I am grateful for comments and suggestions provided by Mark Carey, Paul Harrison, Nellie Liang, Steve Oliner, Jay Ritter, participants at the UCLA Conference: The Equity Premium and Equity Valuations, and the University of Michigan money/macro seminar. I am particularly indebted to Chairman Alan Greenspan for his insights and suggestions during the formative stages of this research. Excellent research assistance was provided by Eric Richards, Dimitri Paliouras, and Richard Thornton. 


\title{
A Reexamination of Stock Valuation and Inflation: The Implications of Analysts' Earnings Forecasts
}

\begin{abstract}
This paper examines the effect of inflation on stock valuations and expected long-run returns. Ex ante estimates of expected long-run returns are constructed by incorporating analysts' earnings forecasts into a variant of the Campbell-Shiller dividend-price ratio model. The negative relation between equity valuations and expected inflation is found to be the result of two effects: a rise in expected inflation coincides with both (i) lower expected real earnings growth and (ii) higher required real returns. The earnings channel mostly reflects a negative relation between expected long-term earnings growth and expected inflation. The effect of expected inflation on required (long-run) real stock returns is also substantial. A one percentage point increase in expected inflation is estimated to raise required real stock returns about one percentage point, which on average would imply a 20 percent decline in stock prices. But the inflation factor in expected real stock returns is also in long-term Treasury yields; consequently, expected inflation has little effect on the long-run equity premium.
\end{abstract}

J.E.L. Classifications: E44, G12 


\section{Introduction}

The relationship between inflation and stock returns has been a thorn in the side of financial economists for over a quarter century. Perhaps the greatest puzzle concerns inflation's role as a conditioning variable for future stock returns. In particular, analysis of monthly and quarterly stock returns--extended most recently by Barnes, Boyd and Smith (1999)-suggests that high expected inflation predicts low stock returns. While inflation's negative effect on expected returns dissipates at longer horizons, the short-horizon findings appear to weigh most heavily on academic perceptions, evidenced by the variety of efforts to construct a compelling rationale for the negative effect, efforts that continue to date. ${ }^{1}$

In this paper, I draw a new perspective on the relationship between stock prices and inflation, and on how inflation affects expected long-horizon stock returns. The starting point in this analysis is the strong negative correlation between the market price-earnings ratio and inflation, a relation which is shown to be quite robust to adjustments for inflation-related distortions in the measurement of accounting earnings. Under the standard present value model of equity valuation, this negative correlation has the following implication: A rise in expected inflation must be accompanied by either (i) a decline in expected long-run real earnings growth or (ii) a rise in the long-run real return required by investors, or both.

I construct a straightforward test of these alternative explanations using an extension of the log-linear dividend-price ratio model of Campbell and Shiller (1988, 1989). In this model, the log of the price-earnings ratio can be written as a linear function of expected (required) future returns, expected earnings growth rates, and the log of expected dividend payout rates.

Assuming we adequately control for expectations of earnings growth and payout rates, then any residual relationship between expected inflation and the log price-earnings ratio can be interpreted as reflecting the relationship between expected inflation and expected long-run returns. In this way, I attempt to discern whether inflation's effect on stock prices arises from its relationship with earnings growth or required returns, or both.

${ }^{1}$ For example, Stulz (1986), Marshall (1992), and Bakshi and Chen (1996) analyze theoretical asset price relationships with inflation using models is which money is desired for transaction purposes, but where the monetary/inflation process has no direct effect on output. 
This approach differs from previous studies in that it emphasizes inflation's effects on long-horizon expected returns; moreover, inferences are based on ex ante measures of expected returns, rather than ex post actual returns. But perhaps the most critical dimension along which my approach departs from previous treatments of this topic is the dominant role assigned to survey expectations in constructing of ex ante measures of expected dividends and returns. In particular, investors' cash flow projections are inferred largely from surveys of equity analysts' earnings forecasts, while inflation expectations are drawn from surveys of professional forecasters.

While having their own disadvantages (perhaps most notably, a sample limited to two decades), survey expectations provide a direct measure of investor forecasts, obviating the need to make strong identifying assumptions on how expectations are formed. ${ }^{2}$ Studies aimed at explaining the relation between expected inflation and stock returns--and much of the broader research on determinants of asset return--infer expectations using linear time series models. But investors may not form expectations in this manner. On the contrary, there is ample evidence to suggest that equity analyst earnings forecasts are impounded into stock prices, suggesting these forecasts are highly correlated with investor expectations. ${ }^{3}$ In fact, the regression analysis below not only supports the hypothesis that analyst forecasts are value-relevant, but it finds these forecasts to have stock price effects that are quite consistent with the model's predictions.

Regarding the main question at hand, our findings suggest that the relation between the market price-earnings ratio and inflation is the result of both hypothesized effects; that is, a rise in expected inflation reduces equity prices because higher inflation is associated with lower expected real earnings growth as well as higher required real equity returns. Surprisingly, the

${ }^{2}$ The argument for measuring expectations directly is analogous to that in Froot (1989), where survey expectations are used to test the expectations hypothesis of the term structure, producing inferences that differ markedly from earlier studies.

${ }^{3}$ For example, La Porta (1996) and Dechow and Sloan (1997) find PE ratios and other valuation measures to be higher at firms with higher earnings growth forecasts (analyst consensus forecasts from I/B/E/S); they also find that returns on firms' stocks are positively related to analysts' forecast revisions or the gap between actual and predicted earnings growth. Liu and Thomas (1999) is one of the most recent studies to find a strong statistical link between stock returns and contemporaneous changes in analyst earnings forecasts. 
earnings channel is not merely a reflection of inflation's propensity to signal recessions. Rather, a substantial part of the negative valuation effect appears to be the result of a negative correlation between expected inflation and expected longer-term earnings growth.

The implied effect of expected inflation on required equity returns is also substantial. Roughly speaking, our estimates suggest that a one percentage point increase in expected inflation raises required long-run real equity returns about three-quarters of a percentage point, accomplished by roughly a 20 percent decline in the current level of stock prices. But this expected inflation factor in equity returns appears to be subsumed by the factor associated with long-term bond yields. In fact, expected inflation appears to have little effect on the long-run equity premium, that is, the expected return premium on equities relative to long-term Treasury bonds.

The paper proceeds as follows: Section II reviews previous research on the topic. Section III introduces the Campbell-Shiller dividend-price ratio model and develops the variant used in the empirical analysis. Section IV provides a description of the data and empirical methodology and lays out the specific predictions of the model. Section V discusses the empirical findings, including tests of the model and hypothesis tests with regard to expected inflation's effect on equity valuations. In section VI, explicit ex ante estimates of expected long-run stock returns are constructed, allowing a direct analysis of the relation between expected stock returns, bond yields, and expected inflation.

\section{Previous Research}

The traditional view that expected nominal returns on assets should move one-for-one with expected inflation is first attributed to Irving Fisher (1930). Financial economists also argued that, because stocks are claims on physical, or "real", assets, actual stock returns ought to co-vary positively with actual inflation, thereby making them a possible hedge against unexpected inflation. During the 1970s, however, investors found that little could be further from the truth; at least in the short and intermediate run, stocks prices apparently were quite negatively affected by inflation, expected or not.

The earliest studies mainly document the negative covariation between actual equity 
returns and actual inflation [e.g., Linter (1975), Bodie (1976)]. ${ }^{4}$ With some identifying assumptions, Fama and Schwert (1977) decompose inflation into expected and unexpected inflation and find both pieces to be negatively related to stock returns. Other early studies focused on the negative relationship between inflation and the level of real equity prices, as reflected in dividend yields and price-earnings ratios. Feldstein $(1978,1980)$ argued that much of inflation's negative valuation effect could be explained by inflation non-neutralities in the tax code, such as those arising from inflation-related distortions to accounting profits. Modigliani and Cohn (1979) and Summers (1983) argued, to the contrary, that such an explanation could not account for the styled facts. Instead, they suggested that stock prices may have been distorted by money illusion; stocks appeared to be priced as if investors mistakenly (i) use nominal interest rates to discount real earnings and/or (ii) treat nominal interest expense as a real expense. Ritter and Warr (2000) produce cross-sectional evidence in support of their money-illusion hypothesis.

The dimension of the stock price-inflation puzzle that generated the greatest sustained academic interest, however, was the apparent negative relation between expected inflation and subsequent stock returns. The explanation that garnered early support was known as the "proxy hypothesis". First articulated by Fama (1981), this hypothesis held that (i) a rise in inflation augurs a decline in real economic activity; and (ii) the stock market anticipates the decline in corporate earnings associated with this slowdown. Hence, in regressions of stock returns on inflation--expected inflation in Fama's formulation--the effect of inflation is spurious; that is, inflation merely acts as a proxy for anticipated real economic activity.

Geske and Roll (1983) and Kaul (1987) further analyzed the negative relation between expected inflation and stock returns, elaborating upon the underlying link between expected inflation and expected real activity. They find support for the basic idea that, once one controls for the link between expected inflation and expected real activity, one is less likely to reject the traditional view that expected inflation or increases in expected inflation cause lower real stock returns. One pattern that shows through the various empirical studies is that the anomalous negative effect of expected inflation on returns tends to diminish at longer horizons. Perhaps most notable in this regard is the Boudoukh and Richardson (1993) study of about one hundred

${ }^{4}$ That negative covariation is most recently confirmed by Hess and Lee (1999). 
years of data, where expected inflation is found to have a positive and nearly one-for-one effect on nominal five-year stock returns. ${ }^{5}$

Boudoukh, Richardson, and Whitelaw (1994) test the cross-sectional implications of the proxy hypothesis by examining the extent to which the pattern of expected-inflation "betas" for stock portfolios of two-digit industries reflect differences in industry sensitivities to inflation and the business cycle. Indeed, they find that the negative effect of both expected and unexpected inflation on stock returns tends to be largest for industries whose output is most cyclical and most negatively correlated with expected inflation.

In the case of unexpected inflation, the interpretation of their results is quite intuitive: news on inflation is correlated with news on future earnings prospects and/or required returns. ${ }^{6}$ For example, an unexpected rise in inflation may raise the risk of countercyclical monetary policy, which is likely to reduce expected real earnings growth and/or raise investor discount rates. Indeed, Thorbecke (1997) provides compelling evidence that tighter monetary policy has a significant negative effect on stock prices, though whether this reflects an earnings channel or discount rate channel remains unresolved. ${ }^{7}$

My analysis is also related to the broader literature on time-variation in expected stock returns and the covariation of stock and bond returns. Research over the last decade and a half

${ }^{5}$ It remains on open question as to how much of the "spurious" inflation effect reflects the correlation of expected returns with ex ante expected inflation, versus the correlation of unexpected returns with unexpected inflation (or changes in expected inflation). Statistical tests generally involve regressing stock returns on estimates of expected inflation, and then adding a measure of changes in expected output, such as leads of ex post output growth. If adding such proxies for expected output "knocks out" the coefficient on inflation, then the proxy hypothesis is accepted. As argued by Boudoukh, Richardson and Whitelaw (1994), this approach lacks the structure needed to draw quantitative inferences.

${ }^{6}$ But Boudoukh, et al. focus mostly on the effect of expected inflation on subsequent returns, and here the mechanism is not so intuitive. As their model makes quite clear, for high ex ante expected inflation to lower expected returns, investors must require lower real returns on stocks when inflation is higher. At the cross-sectional level, their model and results suggest that investors require a lower real return on those stocks for which real dividend growth is negatively correlated with inflation.

${ }^{7}$ Patelis (1997) and Jensen, Mercer, \& Johnson (1996) also examine the effects of monetary policy on stock market returns. 
has generated strong evidence of predictable time-variation in the expected equity returns, at least some of which appears to be linked to the business cycle. ${ }^{8}$ Several financial variables, including the dividend yield on stocks and the term and default risk premiums on bonds, appear to be robust predictors of real or excess returns on stocks, especially over longer horizons [e.g., Campbell and Shiller (1988), Fama and French (1989), Chen (1991)]. Those factors also appear to account for a great deal of the common variation in expected returns on stocks and bonds. ${ }^{9}$ I examine whether expected inflation has marginal explanatory power for expected returns after controlling for other factors.

\section{Model of expected returns based on the price-earnings ratio}

Campbell and Shiller (1988) show that the log of the dividend-price ratio of a stock can be expressed as a linear function of forecasted one-period rates of return and forecasted oneperiod dividend growth rates; that is,

$$
\log \frac{D_{t}}{P_{t}}=E_{t}\left[\sum_{j=1}^{\infty} \rho^{j-1} r_{t+j}-\sum_{j=1}^{\infty} \rho^{j-1} \Delta d_{t+j}\right]+k
$$

where $D_{\mathrm{t}}$ is dividends per share in the period ending at time t, $P_{t}$ is the price of the stock at $\mathrm{t}$. On the right hand side, $E_{t}$ denotes investor expectations taken at time t, $r_{t+j}$ is the log return during period $t+j$, and $\Delta d_{t+j}$ is dividend growth in $t+j$, calculated as the change in the log of dividends per share. The $\rho$ is a constant less than unity, which can be thought of as a "discount factor". Campbell-Shiller show that $\rho$ is best approximated by the average value over the sample period

${ }^{8}$ Rouwenhorst (1995) and Campbell (1998) summarize research findings that contribute to this newer consensus view.

${ }^{9}$ Shiller and Beltratti (1992) go beyond identifying common factors in stocks and bonds. They test whether stock prices are too sensitive to bond yields to be consistent with a constant risk premium between stocks and short-term bonds. Their test is based upon a comparison of the actual correlation between stock prices and bond yields with the correlation implied by a linear VAR system estimated on the dividend yield, real dividend growth, and the spread between long- and short-term bond yields. They find that stock prices are more sensitive to real interest rate shocks than warranted by the theoretical relation implied by VAR estimates. 
of the log of the ratio of share price to the sum of share price and per share dividend, or $\log \left[P_{t} /\left(P_{t}+D_{t}\right)\right] . k$ is the constant that ensures the approximation holds exactly in the steadystate growth case. In that special case, where the expected rate of return and the dividend growth rate are constant, equation (1) collapses to the Gordon growth model: $D_{t} / P_{t}=R-G$.

The Campbell-Shiller log-linear dynamic growth model is convenient because it allows the use of linear regression techniques for testing hypotheses. As pointed out by Nelson (1999), the Campbell Shiller dividend-price ratio model can be reformulated, or expanded, by breaking the log dividends per share term into the sum of two terms, log earnings per share and the log of the dividend payout rate. When this is done and terms are rearranged, the Campbell-Shiller formulation can be rewritten as:

$$
\log \frac{E P S_{t}}{P_{t}}=E_{t}\left[\sum_{j=1}^{\infty} \rho^{j-1} r_{t+j}-\sum_{j=1}^{\infty} \rho^{j-1} g_{t+j}-(1-\rho) \sum_{j=1}^{\infty} \rho^{j-1} \phi_{t+j}\right]+k
$$

where $E P S_{t}$ represents earnings per share in the period ending at $t, \mathrm{~g}_{\mathrm{t}+\mathrm{j}}=\Delta \log \mathrm{EPS}_{\mathrm{t+ \textrm {j }}}$, or $\log$ earnings per share growth in $t+j$, and $\phi_{\mathrm{t}+\mathrm{j}}=\log \left(\mathrm{D}_{\mathrm{t}+\mathrm{j}} / \mathrm{EPS}_{\mathrm{t}+\mathrm{j}}\right)$, the $\log$ of the dividend payout rate in $t+j$.

This reformulation is particularly convenient here because it enables us to focus on earnings growth. To simplify data requirements and focus those requirements on earnings (as opposed to dividend) forecasts, the expected trajectory of the payout ratio is assumed to be characterized by a simple dynamic process. In particular, reflecting the payout ratio's historical tendency to revert back toward some target level following significant departures, I assume that investors forecast the (log) dividend payout ratio as a stationary first-order autoregressive process:

$$
E_{t} \phi_{t+j}=\lambda \phi^{*}+(1-\lambda) \phi_{t+j-1}
$$

In words, the payout rate is expected to adjust toward some norm, $\phi^{*}$, at speed $\lambda<1$.

It is straightforward to show that, given (3), the discounted sum of expected log payout ratios in (2) can be written as: 


$$
E_{t} \sum_{j=1}^{\infty} \rho^{j-1} \phi_{t+j}=\frac{1-\lambda}{1-\rho(1-\lambda)} \phi_{t}+\frac{\lambda /(1-\rho)}{1-\rho(1-\lambda)} \phi^{*}
$$

Substituting expression (4) into equation (2) and combining constant terms yields:

$$
\log \frac{E P S_{t}}{P_{t}}=E_{t} \sum_{j=1}^{\infty} \rho^{j-1} r_{t+j}-E_{t} \sum_{j=1}^{\infty} \rho^{j-1} g_{t+j}-\alpha \phi_{t}+k^{*}
$$

where $\alpha \equiv \frac{(1-\rho)(1-\lambda)}{1-\rho(1-\lambda)}$ lies between 0 and 1 , and the second term in (4) is embedded in $k^{*}$. Note that the weights on the expected returns and on the earnings growth rates sum to $1 /(1-\rho)$. Thus, multiplying both sides of (5) through by (1- $\rho)$ and rearranging terms produces an expression for the expected long-run weighted-average return on equity:

$$
R_{t}=(1-\rho) \log \frac{E P S_{t}}{P_{t}}+E_{t} \sum_{j=1}^{\infty}(1-\rho) \rho^{j-1} g_{t+j}+(1-\rho) \alpha \phi_{t}+c^{*}
$$

where $R_{t} \equiv E_{t}(1-\rho) \sum_{j=1}^{\infty} \rho^{j-1} r_{t+j}$. In words, the expected long-run average log return on equity is approximated by a linear function of (i) the current log earnings-price ratio, (ii) a weighted average of expected earnings growth rates, and (ii) the current log dividend-payout rate. Expressions (5) and (6) provide the basis for the empirical analysis that follows.

Ultimately, equation (6) is used to construct estimates of the expected long-run return on equity, up to a constant, by applying data on analysts' forecasts of earnings growth, together with estimates of $\rho$ and $\lambda$ (and thus $\alpha$ ) and an assumption on expected earnings growth beyond analysts' projection horizon. Given these assumptions, we can test hypotheses on the properties of the expected long-run return on equity, particularly regarding its relationship with expected inflation.

Before constructing such estimates, I employ regression analysis to test the assumptions embodied in the model, including the value-relevance of our survey-based proxies of expected earnings growth. Specifically, I estimate regression models with the log price-earnings ratio as dependent variable, which allows a joint test of (i) the model, (ii) the hypothesis that analysts' forecasts are incorporated into stock prices and (ii) any hypotheses on the time-variation in 
expected (long-run) stock returns. The regression analysis is a particularly useful way to incorporate analysts' longer-term growth forecasts, which do not have a precise structural interpretation like the forecasts of earnings one and two years out.

Though (5) is fairly similar to the original version of the model used by Campbell and Shiller, my implementation differs substantially. In their analysis, estimates of rational market expectations of future real dividend growth are generated under the assumption of a stable linear time series relationship between dividend growth rates, the dividend-price ratio, and sometimes other variables. These restrictions are tested jointly with alternative assumptions on the behavior of expected real returns. In contrast, our estimates of expected dividends are based upon surveys of equity analysts' forecasts of future earnings growth, coupled with a simple autoregressive model of the payout rate. Using analyst expectations as data simplifies the analysis substantially, and obviates the need to assume that investors form their expectations like econometricians.

\section{Data and Empirical Methodology}

\section{A. The data and construction of variables}

Monthly survey data on analyst earnings forecasts and historical annual operating earnings for the S\&P 500 come from I/B/E/S International. Earnings expectations for the S\&P 500 are constructed by I/B/ES from their monthly surveys of equity analysts for their forecasts of firm-level earnings for the current and subsequent fiscal years. Similar to other Wall Street research firms, I/B/E/S specifically asks for estimates of per share "operating" earnings, and uses this concept of earnings to record both expected and actual historical earnings. ${ }^{10}$

Figure 1 shows the price-earnings ratio for the S\&P500 based upon the I/B/E/S measure of operating earnings (over the previous twelve months), alongside the more conventional measure of the PE ratio published by S\&P, which is based upon four-quarter trailing "reported" earnings. Though these series diverge considerably in the early 1990s, when reported earnings were depressed by the many large one-time restructuring charges, they generally move in

${ }^{10}$ This concept of earnings frequently excludes certain expense or income items that are either non-recurring or unusual in nature, such as restructuring charges or capital gains/losses on unusual asset sales. In contrast, such items are reflected in "reported" earnings, as measured by Standard \& Poor's in their calculation of earnings per share (for the S\&P 500). 
Figure 1

\section{Price-Earnings Ratios versus Inflation}

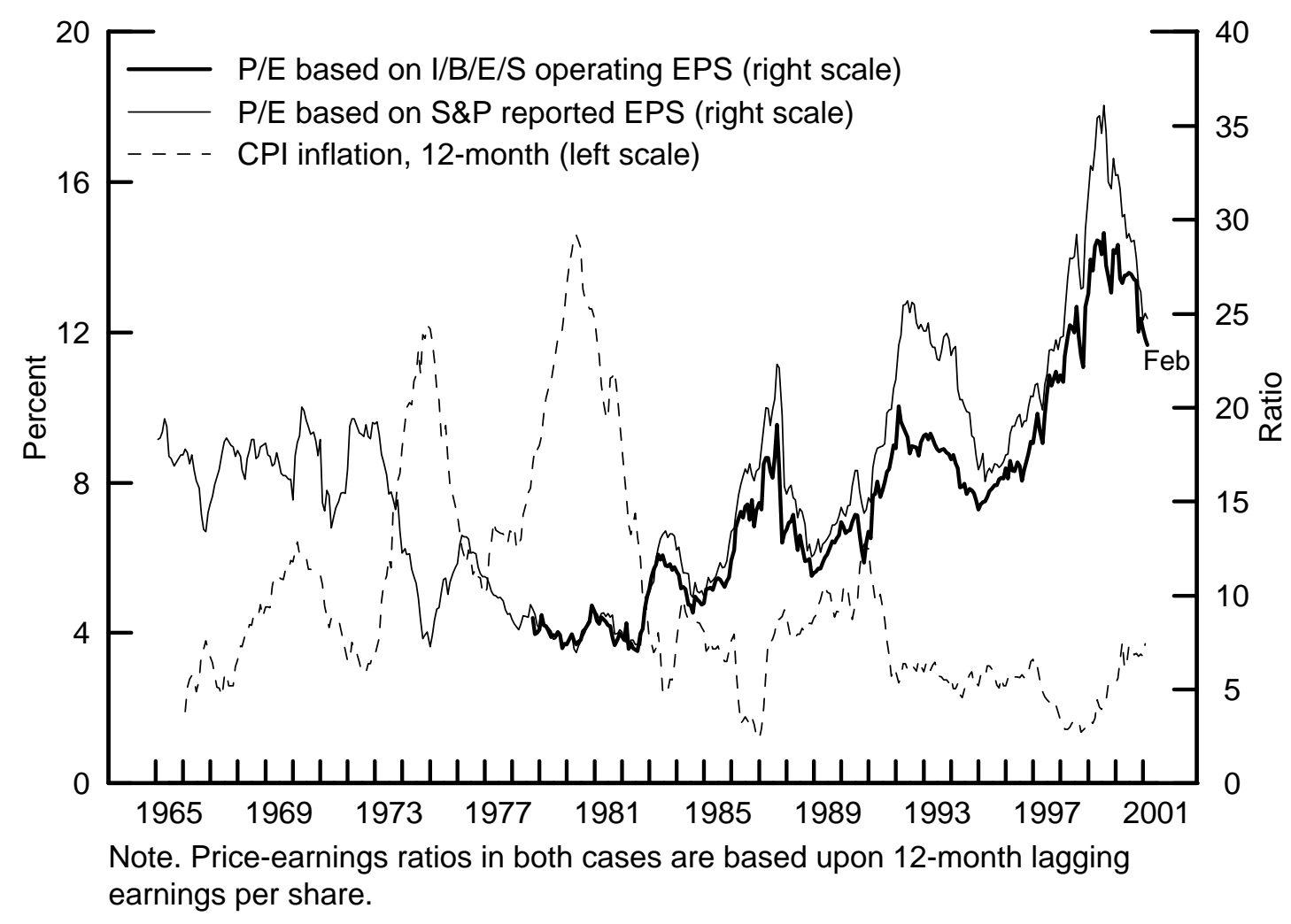


tandem. By either measure, the PE shows a strong negative correlation with inflation, gauged here by the 12-month change in the CPI.

Beginning with "consensus" (mean) forecasts for individual companies, I/B/E/S constructs estimates of aggregate S\&P 500 earnings per share in the previous (EPS0), current (EPS1), and forthcoming (EPS2) calendar years. ${ }^{11}$ Forecasts of aggregate S\&P 500 earnings per share for any given calendar year are constructed monthly beginning in February of the preceding year. Thus, in February of each year, roughly two full years of earnings forecasts are available, whereas, in December, most forecasts look forward only 13 months. From these calendar-year estimates, I define the February values of the earnings variables as follows: (i) 12-month lagging earnings per share, $E P S_{0}=E P S O$; (ii) expected current-year EPS growth, $g_{1}=\log (E P S 1)-\log (E P S O)$; and (iii) expected growth next year, $g_{2}=\log (E P S 2)-\log (E P S 1)$.

To take advantage of the higher frequency of the data, approximations are used to define values for these variables outside of February. The monthly values for 12-month lagging earnings per share (used in the price-earnings ratio in Figure 1) are constructed as a weighted average of the previous year's earnings and expected current-year earnings; specifically, $E P S_{0}=w_{m} * E P S O+\left(1-w_{m}\right) * E P S 1$, where $w_{\mathrm{m}}$ equals 1 in February, 11/12 in March, 10/12 in April, and so on, ending at $1 / 12$ the following January. $E P S_{0}$ is also used to construct the lagged dividend payout rate, which is measured as lagging annualized dividends per share--the numerator of the S\&P 500 dividend yield published by Standard \& Poor's--divided by $E P S_{0}$.

The approximation used to construct non-February values of expected current-year earnings growth, $g_{1}$, is an extension of that used for $E P S_{0}$ :

$$
g_{1}=\log \left(w_{m} * E P S 1+\left(1-w_{m}\right) * E P S 2\right)-\log \left(w_{m} * E P S 0+\left(1-w_{m}\right) * E P S 1\right)
$$

where $w_{m}$ is the same month-specific weight. Finally, non-February values of $g_{2}$ are calculated no differently than in February $(\log (E P S 2)-\log (E P S 1))$, as there is no EPS3 variable for creating a weighted average to represent earnings in the year beginning 12 months ahead. Thus, whereas,

${ }^{11}$ To do so, firms' earnings are "calendarized", meaning that a firm's fiscal year earnings are associated with the calendar year in which it has the most overlap. 
in February, $g_{2}$ refers to expected growth beginning 12 months out, that horizon gradually moves in as the calender year progresses; and by December, $g_{2}$ is nearly the same as $g_{1}$.

A perspective on the historical behavior of these earnings forecasts is provided in Figure 2 , where I have plotted $\left(g_{1}+g_{2}\right) / 2$, the average of expected growth in the current year and next. The dark circles mark the values of the expected average growth rate in February, when expectations cover a full two-year horizon. As can be seen, the expected growth rate during 1979-1998 fluctuated mostly between 10 and 25 percent, a range which can justify a fairly large swing in equity valuations. Holding all else constant, the model suggests that a 15 percentage point jump in the expected growth rate for the next two years would justify a nearly 30 percent rise in the price-earnings ratio, or a 30 percent rise in price, given current earnings. ${ }^{12}$

It is interesting to compare expectations with what actually transpired. The bars show the actual growth rate that transpired over the two years ahead, the period on which forecasts (in February) are trained. For instance, the bar furthest to the right depicts average growth in 1999 and 2000, which was below expectations in February of 1999. Consistent with previous analysis of firm-level data, this chart shows a fairly strong upward bias in analyst growth forecasts. ${ }^{13}$ The average difference between the projected and the actual growth rate is 8.5 percentage points; and, there are only 2 instances when analysts underestimated aggregate two-year earnings growth. Nonetheless, forecasts do seem to have predictive content; regressing actual growth on expected growth (using only February observations) yields a statistically significant coefficient of 0.95 on expected growth, with an R-squared of .21.

The final earnings expectation variable is the long-term growth forecast, which I construct as a weighted average of the forecasted long-term earnings growth rates for each of the $\mathrm{S} \& \mathrm{P} 500$ constituents in any given month. Each firm-level figure is the I/B/E/S consensus (median analyst) forecast of the expected annual growth rate in operating earnings over the next three to five years. Ideally, the growth forecasts are aggregated using each company's share of recent aggregate earnings. To minimize the problem arising from a negative earnings base, each

${ }^{12}$ Specifically, $\Delta \log \mathrm{EPS} / \mathrm{P}=\Delta \mathrm{g}_{1}+\rho \Delta \mathrm{g}_{2}$, where $\rho$ is about 0.96 .

${ }^{13}$ For example, Claus and Thomas (1998) find that, in every year of their sample and at every forecast horizon, the median firm-level forecast error is positive, and usually quite large. 
Analyst Forecasts of Growth in S\&P 500 Earnings Per Share

Average of current-year and following-year growth

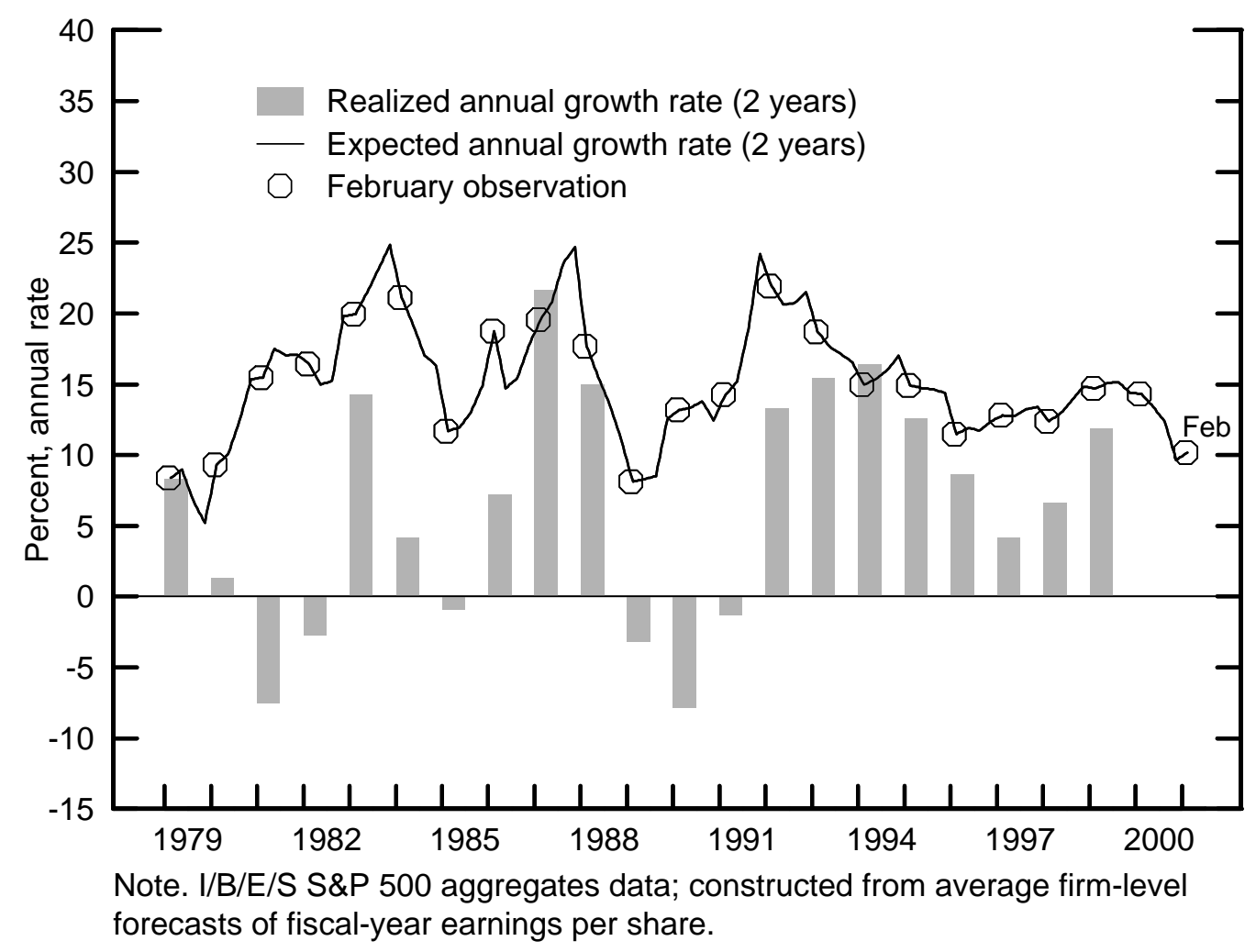


company's weight is set equal to the maximum of the forecasts for the current and following years' earnings. In the rare circumstance where both are negative, the firm receives zero weight. $^{14}$

The resulting series is depicted by the solid line in Figure 3. The sample period is limited further by this series, because firm-level estimates only became widely available in the I/B/E/S data in 1983. As can be seen from the right-hand scale, historically, this series has moved within a relatively narrow band; it also displays a high degree of autocorrelation. As one might expect, the long-term growth forecast was relatively high in early 1983, when the economy had just emerged from a deep recession. Similarly, growth expectations peak again in 1992, on the heels of the 1990-91 recession. But the most striking feature of this series is the unprecedented rise beginning in mid-1995.

Shown alongside the long-term growth forecast is the expected inflation rate over the next 10 years, as gauged by the quarterly Philadelphia Fed survey of professional forecasters (taken in the second month of each quarter). ${ }^{15}$ The figure shows a negative relationship between expected long-term inflation and expected long-term nominal earnings growth, which implies an even stronger negative correlation between expected inflation and real, or inflation-adjusted expected long-term growth. This foreshadows one of the main conclusions of this study: at least in part, inflation is associated with low stock valuations at least because higher inflation with lower real earnings forecasts.

${ }^{14}$ Even ignoring the problem arising from negative earnings, the long-term growth forecast is a fairly ambiguous concept, and is interpreted in different ways by different analysts. Some treat it literally as the expected growth rate from the recent base, while others apply a cyclically-adjusted concept, such as a peak-to-peak growth forecast. Moreover, there is no clear consensus on the horizon analysts have in mind. Thus, rather than impose more structure, I let the empirical results influence the interpretation.

${ }^{15}$ Prior to 1992 , there are several quarters in which no survey value exists; sometimes values are missing for two of a year's four quarters. In contrast, there are no missing values in the Philadelphia Fed's survey of 4-quarter inflation expectation series, which is highly correlated with the 10-year expectation series. I fit a 3-region spline regression of the 10-year expectation on the 4-quarter expectation to construct estimates of the 10-year expectation in those quarters with missing values. 
Figure 3

\section{Analyst Forecasts of Long-term Nominal Growth in S\&P 500 Earnings Versus Expected Inflation}

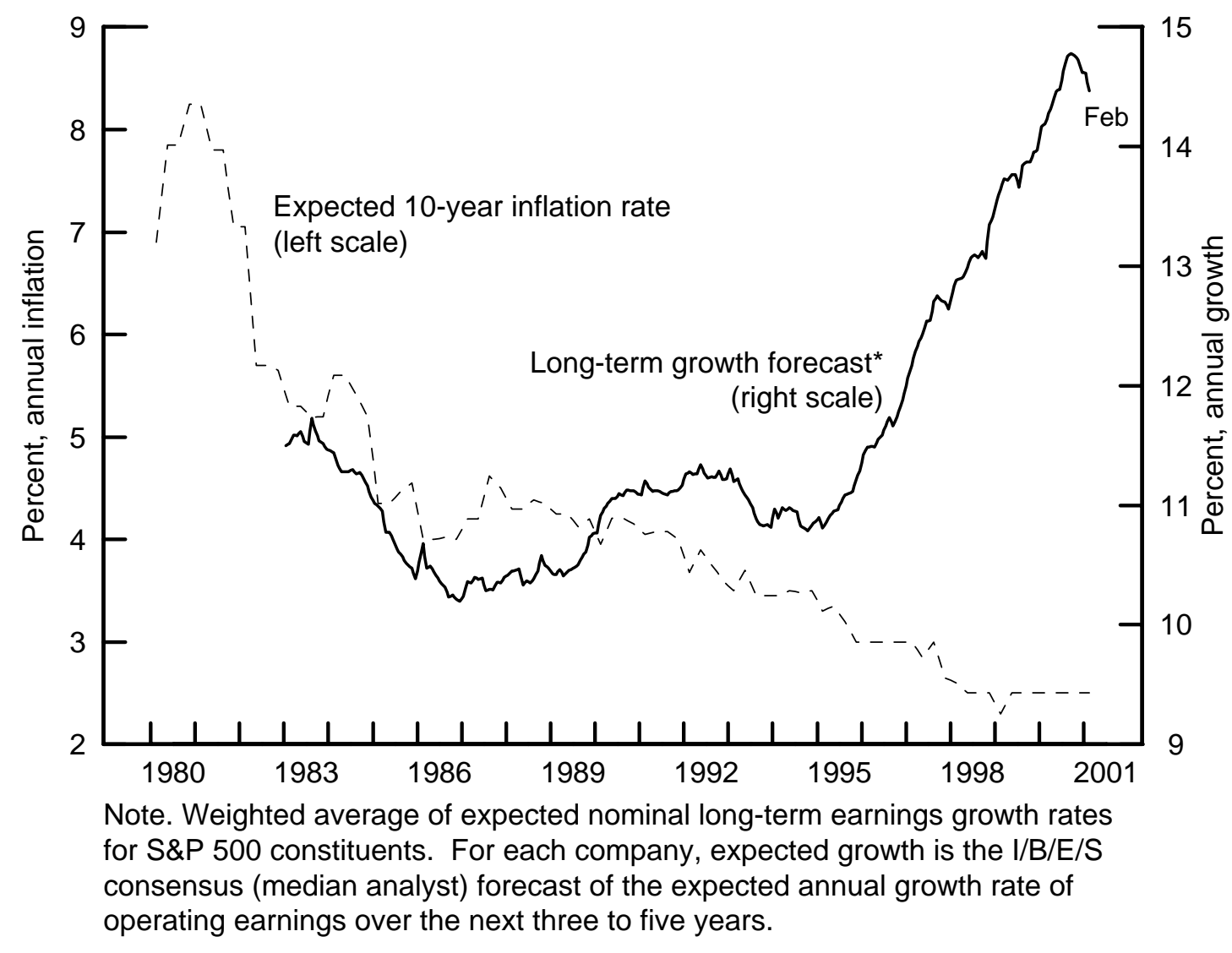




\section{B. Methodology for hypothesis testing}

To test model (5) and the value-relevance of analysts' aggregated expectations, I estimate the following regression using quarterly data:

$$
\log \frac{P}{E P S_{0}}=c+\beta_{1} g_{1}+\beta_{2} g_{2}+\beta_{2} g_{L T}+\alpha \cdot \log \left(\text { payout }_{0}\right)+\gamma Z+u
$$

where the time subscript is suppressed for notational simplicity. Consistent with the timing of the expected inflation survey, other variables are measured in the middle month of each quarter.

The dependent variable is the ratio of the current S\&P500 price to 12-month-lagging earnings per share (equation (5) is multiplied through by -1). As just described, the independent variables $g_{1}, g_{2}$, and $g_{L T}$ represent analyst forecasts of EPS growth for current year, the following year, and the "long term". For reasons explained below, the regression analysis is performed on real, or inflation-adjusted, variables. Earnings forecasts are transformed into real growth forecasts by deducting expected inflation, that is, by subtracting the expected four-quarter inflation rate from $g_{1}$ and $g_{2}$ and the 10-year expected inflation rate from $g_{L T}$. The variable $\log \left(\right.$ payout $\left._{0}\right)$ is the log of the lagged dividend payout rate; being a ratio of two nominals, no transformation is required. Also appearing in the regression is a vector of variables $(Z)$--most notably, expected 10-year inflation--that are hypothesized to be factors in long-run expected equity returns. Finally, the random disturbance term, $u$, is assumed to be stationary and uncorrelated with the explanatory variables. The benchmark specification assumes $u$ to follow a 1st-order autoregressive process.

\section{Predicted coefficients: earnings and dividend variables}

Any textbook valuation model would imply positive betas on the earnings growth and dividend payout variables. Under the assumption that key variables are not mismeasured or omitted, equation (5) offers more specific predictions. In particular, the model implies that the coefficients on $g_{1}$ and $g_{2}$ should equal 1.0 and $\rho$, respectively (where, again, $\rho$ is slightly less than one, such as 0.95 ). The coefficient on $g_{L T}$ should be positive and exceed 1. More precisely, if this statistic represented expected growth over the next $\mathrm{T}$ years, the coefficient on $g_{L T}$ should 
equal $\sum_{j=1}^{T} \rho^{j-1}$. For instance, if it represented a 5-year expectation as often advertised, the predicted coefficient would be about 4.5. Even so, the potential redundancy from including $g_{l}$ and $g_{2}$ in the regression may reduce the coefficient on long-term growth (as well as on $g_{1}$ and $g_{2}$ ). On the other hand, to the extent that expected growth beyond 5 years-the omitted variable-is correlated with $g_{L T}$, the coefficient on $g_{L T}$ may be inflated.

The model also puts restrictions on $\alpha$, the coefficient on the log dividend payout rate. As shown earlier, the assumed autoregressive behavior of the payout rate implies that $\alpha$ should fall between 0 and 1. Moreover, the upper end of that range can be ruled out if shocks to the payout rate are not extremely persistent, that is, if $1-\lambda$ is too close to 1 . In a simple annual regression of the log payout rate on its 12-month lag, I estimate a coefficient of about 0.75 on the lag. Thus, the autoregressive parameter perceived by investors arguably ought to be reasonably close, perhaps within a range like 0.6 to 0.9 . With $\rho=0.96$, this translates into a point estimate for $\alpha$ equal to 0.11 , and plausible range of 0.06 to 0.27 . Thus, the model suggests that, by itself, a temporary change in the current dividend payout rate should have little effect on equity prices. For instance, a 10 percent decline in the current dividend payout rate (holding earnings constant) should only raise stock prices between 0.6 and 2.7 percent.

\section{Proxies for expected returns}

Assuming these variables adequately control for earnings and dividend growth expectations, then, in a regression such as (6), any residual effect of expected inflation on the log price-earnings ratio would reflect its effect on expected, or required, long-run returns. Of course, such a test is based on the null hypothesis that expected stock returns are not time-varying, a null that most of the profession would probably now view as a strawman. A more interesting question is whether expected inflation is a significant factor for expected stock returns once we control for other factors viewed as plausible conditioning variables for expected returns.

Researchers have documented a strong commonality between expected returns on stocks and expected returns or yields on bonds [e.g., Keim and Stambaugh (1986), Campbell (1987), Fama and French (1989)]. The most familiar characterization is the finding that the excess returns on stocks versus short-term riskless bonds is positively related to ex ante term premia on long-term bonds. The analogy to conditioning excess stock returns on the term premium would 
be to condition stock returns on the long-term bond yield. Thus, in some regressions, I include the expected real yield on 30-year Treasury bonds, defined as the 30-year Treasury bond yield less the expected 10-year inflation rate.

Previous findings and most models predict a negative coefficient for the expected real long-term bond yield: ceteris paribus, high real interest rates indicate a high required return, and thus a low current stock price. Under the hypothesis that investors require a constant return premium on stocks versus bonds--or an equity premium that is uncorrelated with expected real bond returns--the model offers a sharper prediction. For instance, assuming a constant risk premium and a flat term structure for expected one-period returns, then the coefficient on the Treasury bond yield should equal $-1 /(1-\rho)$, the sum of the weights on expected future oneperiod returns in equation (5), which equals -25 for $\rho=.96$.

As shown by Fama and French (1989), default risk spreads also appear to be an important class of conditioning variables for long-horizon stock returns. They find that long-run stock returns are positively related to an ex ante default risk spread, and argue that this variable serves as a proxy for a long-term cyclical component in expected returns. Thus, I also include a default risk spread as a conditioning variable for expected returns; in particular, I use the spread between yields on Baa-rated and Aaa-rated industrial bonds, based upon Moody's monthly bond yield indexes. Like the long-term bond yield, this variable is expected to have a negative effect on the price-earnings ratio.

\section{E. Distortions to accounting earnings}

A potentially important measurement problem that confronts any earnings-based valuation model is that accounting earnings are a noisy measure of true economic earnings. Of particular concern in this study are the discrepancies between accounting earnings and economic earnings that are exacerbated by inflation. ${ }^{16}$ Indeed, inflation-induced distortions to earnings

${ }^{16}$ Another measurement issue arises from the distinction between "reported" and "operating" earnings. Firm-level studies of the relationship between earnings and stock prices that use reported earnings, such as "net income before extraordinary items" from Compustat, tend to find relatively small effects of changes in earnings on stock prices. Such studies are probably hampered by the presence of large jumps in earnings associated with unusual (but not "extraordinary") events, particularly restructuring charges and capital gains or losses on asset 
caused by historical cost accounting was a topic of great interest and concern in the 1970s and early 1980s, and a number of studies attempted to characterize and gauge these distortions. ${ }^{17}$

In principle, distortions in accounting earnings need not distort estimates of expected return generated by our model. This is because the ultimate source of value in (5) is the discounted stream of expected dividends; that is, this model is merely a rearrangement of the terms in Campbell and Shiller (1988), in which expected return is calculated as a function of dividend growth and the dividend price-ratio. As shown in the appendix, as long as earnings and expected earnings are measured in a consistent fashion, any measurement problem embodied in the earnings-price ratio and the earnings growth terms would be offset by distortions in the dividend payout terms--the $\varphi$ 's--with equal and opposite effect.

Nonetheless, in practice, the presence of accounting distortions is likely to bear on the validity of any particular set of assumptions on unobservables, such as the assumed dynamics of the expected payout rate or assumptions regarding the expected growth of (accounting) earnings beyond analysts' forecast horizons. ${ }^{18}$ Thus, I construct a control variable that measures the wedge between lagged accounting and economic earnings.

As emphasized by Modigliani and Cohn (1979), and more recently by Ritter and Warr (2000), high inflation amplifies two prominent distortions in accounting profits: (i) the understatement of economic depreciation expense by accounting "book-value" depreciation, and (ii) the overstatement of economic debt-service expense by reported interest expense. The size of these distortions in S\&P500 earnings can be gauged using data from the National Income and Product Accounts (NIPAs), under the assumption that the distortions are spread proportionally

sales. Such events often reflect information already in the public domain, and which are expected to have little effect on earnings going forward. This type of measurement issue is avoided by using I/B/E/S data for actual historical (as well as expected) earnings.

${ }^{17}$ See von Furstenburg and Malkiel (1977), Shoven and Bulow (1976, 1977), and Scanlon (1981). Feldstein and Summers (1978) and Feldstein (1980) examine measurement distortions associated with inflation and how they interact with effective tax rates.

${ }^{18}$ For example, the stochastic process assumed for the log payout rate in (5) is less compelling in the presence of accounting distortions. In the presence of such distortions, the expected dynamics of the expected (log) payout rate will depend not only on the expected evolution of the true payout rate, which is arguably cyclical, but also on the expected dynamics of any distortions to measured earnings. 
throughout the aggregate U.S. corporate sector.

The extent to which earnings are overstated as a result of historical cost-based depreciation methods can be estimated using the NIPA current-cost adjustment, the component of the capital consumption adjustment that converts aggregate U.S. corporate depreciation from a book-value basis to a replacement-cost basis. This adjustment, expressed as a fraction of total after-tax NIPA profits, is shown by the light solid line the upper panel of figure 4. It grows more negative during the period of rising inflation and then only gradually reverts back toward zero after inflation falls off in the early 1980's. ${ }^{19}$

The interest expense reported in financial statements tends to overstate true economic debt-service expense because the portion of interest expense that compensates creditors for inflation is not an economic expense; rather, as explained quite thoroughly by Ritter and Warr (2000), it represents compensation for the gain a debtor realizes when inflation depreciates the value of its nominal liabilities. I construct an adjustment for depreciation of real net liabilities in the U.S. corporate sector by multiplying the book value of debt outstanding on the balance sheet of nonfinancial U.S. corporations by the contemporaneous inflation rate. ${ }^{20}$ The resulting adjustment, again expressed as a fraction of aggregate after-tax profits, is shown by the dotted dashed line in the upper panel of figure 4.

Finally, the net adjustment that results from summing these two adjustments is plotted by

${ }^{19}$ The current cost adjustment is one of two pieces that constitute the capital consumption adjustment in the NIPAs, and is only available annually; the annual series is converted to a monthly series using a linear smoothing algorithm. The other piece of the NIPA capital consumption adjustment, unneeded for our purposes, converts depreciation from the tax-based measure in NIPA source data to economic depreciation (at historical cost).

${ }^{20}$ The inflation rate is the four-quarter percent change in the GDP deflator. The aggregate book value of debt is taken to be the outstanding amount of credit market instruments, net of interest-earnings assets on the balance sheet of nonfinancial corporations in the U.S., as estimated from table L.102 in the Flow of Funds Accounts published by the Federal Reserve. This omits any such distortion associated with financial corporations' profits, but the distortion arising from that sector probably contributes little to the total since the financial sector accounts for only about 20 percent of total profits; moreover, the net debt position of financial institutions tends to be small because of their offsetting investments in debt. 


\section{Adjustments for Distortions to Current Economic Earnings}

Fraction of Book Accounting Earnings

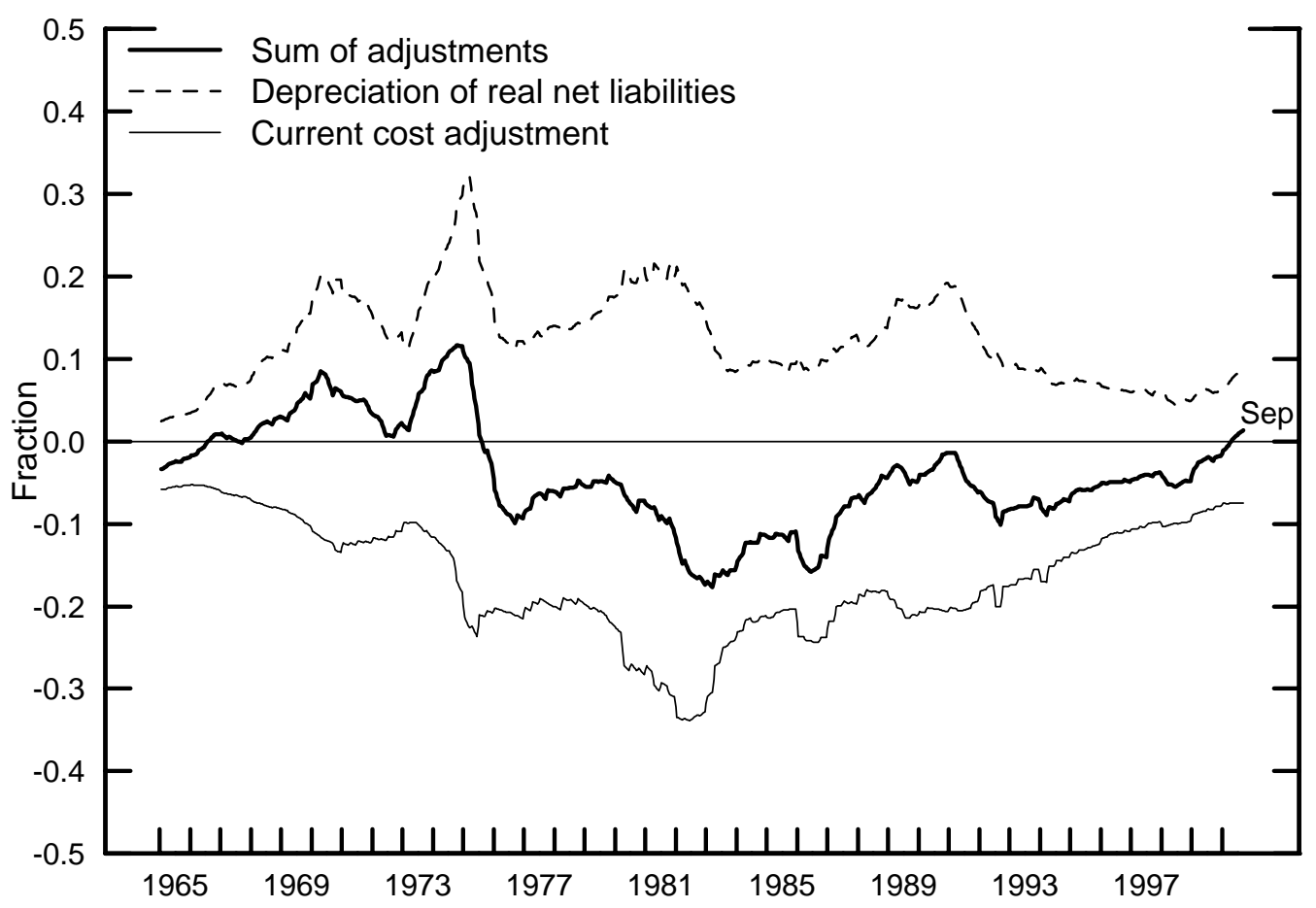

Figure 4a

\section{Adjusted PE Ratio}

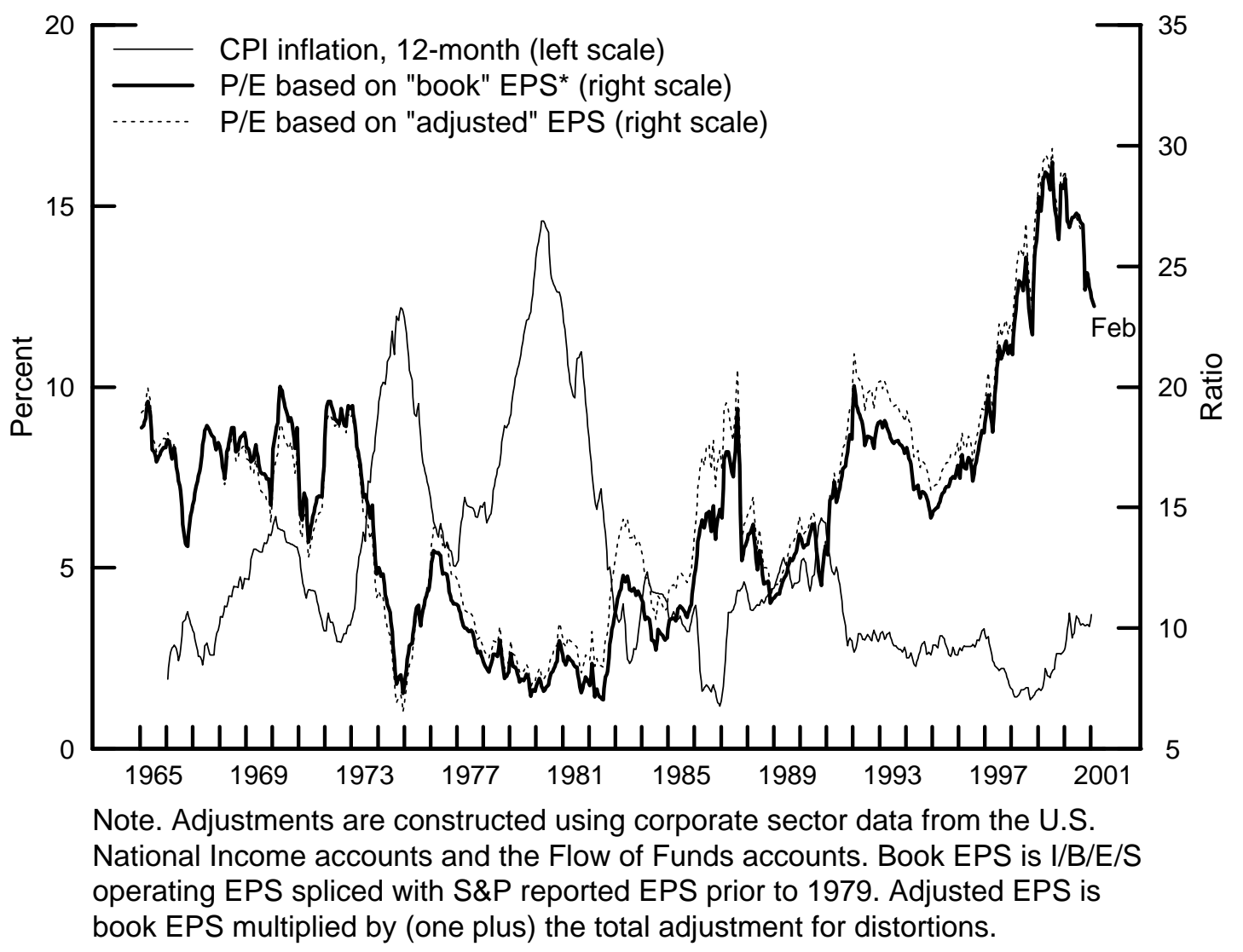


the thick solid line. ${ }^{21}$ As can be seen, in the aggregate the two distortions tend to offset each other. To examine their effect on PE ratios, the net adjustment is used to convert the 12-month lagging earnings series in the I/B/E/S PE ratio into a measure of lagging economic earnings. The resulting "economic" PE ratio is plotted against the unadjusted PE ratio (bottom panel, Figure 4).

While this adjustment generally boosts the PE ratio, particularly in the early 1980s, it has little effect on its general contour. In fact, over the entire period shown, the correlations of the 12-month CPI inflation rate with the alternative PE ratios are practically identical. Similarly, over the period when the survey of expected 10-year inflation is available (1979:Q4 to date), that variable has a correlation of about -.85 with both PE measures. Still, in the analysis that follows, I include a control for the distortion in accounting earnings, equal to the log of the ratio of 12month 12-month lagging economic to accounting earnings.

\section{F. Other specification issues}

Although the theoretical relation (5) is valid in both nominal or real terms, I focus on the real version of the model. In the nominal model, it is more difficult to handle the potential omitted variable problem--the fact that the regression omits a measure of earnings growth for the "out years"--the years beyond the horizon covered by analysts' long-term growth forecasts. As expected 10-year inflation is almost surely correlated with nominal out-year earnings growth expectations, the interpretation of expected inflation's coefficient in the nominal specification becomes complicated. In the real version of the model, the null is straightforward: the hypothesis that expected inflation has no effect on required real returns implies that it should have no effect of the PE ratio, once we control for expected real earnings growth in the short- and intermediateterm, and assume constant real growth expectations for the out years. The analogous hypothesis in the nominal specification would be that expected inflation has a one-for-one effect on expected nominal returns. But this translates into the hypothesis that expected inflation should have a

\footnotetext{
${ }^{21}$ Perhaps the most surprising characteristic of this series is that it is positive in the early 1970s. At that time, the effect of inflation on the distortion associated with book depreciation is still small relative to the distortion associated with the effect of inflation on the value of outstanding debt. This gradually changes because the depreciation distortion cumulates over time as the book value of capital gets more out of line with its replacement cost.
} 
large negative effect on the price-earnings ratio via the expected return channel, tempered by the unobserved and indeterminate effect of expected inflation on expected nominal earnings growth in the out-years. ${ }^{22}$

\section{Empirical Results}

\section{A. Simple Correlations}

Simple correlations are shown in Table 1. In order to illustrate the most basic relations, Pearson correlations are calculated using nominal (unadjusted) earnings growth variables and bond yields. As shown in the first column, the PE ratio is negatively correlated with the dividend payout rate. It is positively correlated with forecasts of long-term earnings growth forecasts, while its correlations with forecasts of near-term earnings growth are less apparent. The PE ratio's correlation with the Treasury bond yield mimics its strong negative correlation with expected inflation. As one might expect, the PE ratio is negatively related to the bond default premium and positively correlated with earnings quality.

\section{B. Main regression results}

The four columns of table 2 show results from regressions of the log price-earnings ratio on expected inflation and various combinations of the model variables; together they illustrate how much inflation's explanatory power is diminished by controlling for fundamentals. All specifications include the control for earnings quality, equal to the log of the ratio of economic to accounting earning. Finally, these specifications include an AR(1) disturbance term, estimated via the Yule-Walker method. The regression R-squared measures the R-squared on the transformed variables, that is, the explanatory power of all variables except the AR(1) term.

The first column reports the regression with expected 10-year inflation as the only explanatory variable, which serve as a benchmark for gauging subsequent results. The

${ }^{22}$ There is also a technical difficulty with the nominal model. Since fluctuations in outyear growth expectations is one source of the disturbance term, assuming the disturbance term is stationary requires the same of those out-year-growth expectations. But long-term nominal growth expectations are less likely to be stationary than real growth expectations, given the evidence of potential nonstationarity in the inflation rate (e.g., Campbell and Shiller, 1989). 
coefficient on expected inflation, -20.08, is sizable, implying that a 1 percentage point increase in the expected 10-year inflation rate is associated with a 20 percent decline in the price-earnings ratio, or a 20 percent decline in stock prices given lagged earnings. The AR(1) coefficient estimate is 0.79 , large though significantly less than unity.

The second regression adds the variables measuring earnings and dividend growth expectations. Adding these variables boosts the R-squared to 0.88 and reduces the AR(1) term. Overall, the coefficient estimates are quite supportive of the model and the joint hypothesis that analyst earnings forecasts are value-relevant. The coefficients on $g_{1}$ and $g_{2}$ are both positive and significant; at 0.76 and 0.98 , neither is significantly different from its theoretical value. The coefficient on long-term growth is positive, significant, and quite large; at 9.4, it is about twice the magnitude predicted by theory if it represented a five-year forecast.

The coefficient on the payout rate variable is positive as predicted by the model. Although it is more than double our point prediction of 0.13 (implied by an autoregression of the log payout ratio on its 12-month lag), it is consistent with plausible speeds of mean reversion in the payout ratio. It is interesting to note that the coefficient on the payout rate could have been negative if the payout rate in this regression primarily served as a proxy for expected returns, as it apparently does in Lamont's (1998) regressions, where a high payout rate predicts high future returns. $^{23}$

Regarding the main hypothesis of interest, adding the proxies for real growth expectations to the regression only dampens the coefficient estimate on expected inflation to -15 , or by 25 percent compared with column (1). Thus, regression (2) results clearly reject the hypothesis that long-run required real stock returns are constant in favor of the alternative that they are positively related to expected inflation.

Arguably, the more interesting question is whether inflation has independent predictive power for long-run expected returns once we admit other factors that are thought to predict longrun returns. A test of this hypothesis is provided by the regression in column (3), which adds two proxies for expected long-run returns--the real 30-year Treasury bond yield and the default

\footnotetext{
${ }^{23}$ Indeed, the payout rate does get a negative coefficient when I regress the PE ratio on the payout rate by itself, or with just the year 1 and year 2 growth forecasts.
} 
premium on Baa-rated bonds. As shown, the estimated coefficient on the expected real bond yield is negative and statistically significant. ${ }^{24}$ The coefficient on the default premium is negative but very small and statistically insignificant. Coefficients on the earnings growth variables are little changed from (2). The coefficient on long-term earnings growth expectations is again quite large; it suggests that a 1 percentage point increase in expected growth increases stock prices 10.6 percent. Finally, with the addition of these proxies for expected return, the coefficient on expected inflation is trimmed to $\mathbf{- 5 . 2}$ and is no longer significant. Thus, once we control for both expected earnings and bond yields, expected inflation no longer helps to explain equity prices.

Based upon regressions (2) and (3), one might conclude that the correlation between equity valuations (PE ratios) and expected inflation arises largely from the positive association between expected inflation and expected returns. However, this notion is countered by specification (4), where bond yields are included and earnings growth variables are excluded. Here, the coefficient estimate on expected inflation is -17 , similar to regression (2). Hence, we are led to the conclusion that both influences--an earnings growth effect and a required return effect--are behind the correlation between inflation and stock valuations. Only when we control for both factors can we explain away the apparent effect of inflation on equity prices.

\section{Robustness}

I consider some alternative specifications to address a couple robustness issues: How sensitive are the results to the assumed dynamics? And, to what extent are they driven by the extraordinary observations from the last few years? Specification (5) begins with (3) but excludes the AR(1) term. Specification (6) instead employs a partial-adjustment (errorcorrection) specification; that is, it includes a lagged dependent variable in place of the AR(1) term. To facilitate comparisons, coefficients shown for (6) are the implied long-run coefficients, $b /(1-\lambda)$, along with the coefficient on the lagged dependent variable, $\lambda$. In both (5) and (6), the Newey-West method is used to compute heteroskedasticity and autocorrelation-consistent standard errors.

${ }^{24} \mathrm{At}-6.7$, this coefficient is modest in magnitude. The hypothesis that expected long-run stock returns move one-for-one with the real bond yield predicts a value around -25 . 
As shown in table 3, specifications (5) and (6) yield conclusions that are quite consistent with the base case. The coefficient on expected inflation remains relatively small, though in (5) it is statistically significant. Also, in both cases, the estimated effect of long-term growth expectations remains quite large. Perhaps the only notable difference is the somewhat smaller pair of coefficients on the shorter-term growth forecasts in (6).

Specification (7) allows us to gauge how sensitive the results are to excluding the extraordinary period of high equity valuations, when long-term growth forecasts similarly were at record highs. In particular, I estimate the base case model (3) on a subsample that ends in 1996. Indeed, in this subsample the coefficient estimate on expected inflation is more negative (-10.96 versus -5.2 ) and statistically significant. At the same time, the coefficient on the long-term growth forecast shrinks to 4.0, significant only at the 10 percent level. Thus, excluding the recent four-year period does temper the strength of the earlier conclusions.

Nonetheless, given the relatively short sample, eliminating some of the data reduces our ability to identify the separate effects of highly correlated variables. For instance, if the earnings growth forecast for year 2 is excluded from this shorter sample regression, the coefficient on long-term growth is boosted to -7.7 , and is significant at the 1 percent level, while the coefficient on expected inflation is diminished. Alternatively, under the hypothesis that expected inflation's effect on equity valuation is spurious, its inclusion in the regression could bias down the coefficient on long-term growth, given their strong negative correlation. Indeed, as shown in column (8), if expected inflation is excluded from the regression, then the coefficient on longterm growth rises to 9.6 and is once again statistically significant.

\section{Interpreting the effect of long-term growth expectations}

Given the importance of analysts' long-term growth forecasts in the results, our interpretation depends critically on the maintained hypothesis, adopted from the accounting literature, that such forecasts are exogenous with respect to stock prices. Previous findings suggest that most types of forecasts by equity analysts violate rational expectations of future earnings, though the properties of long-term growth forecasts have received less attention than shorter-term forecasts. Still, research indicates that analysts' long-term forecasts are not only upward biased but also too extreme, or more upward biased for firms expected to grow fast [e.g., 
Dechow and Sloan (1997), Rajan and Servaes (1997)]. There is also mixed support for the view that analysts over-extrapolate from recent observations [De Bondt (1992), La Porta (1996)].

Such qualities do not necessarily invalidate the utility of these forecasts for explaining stock valuations, and they may well represent analysts' best efforts, even if subject to some institutional constraints. The more problematic issue is the possibility that analysts adjust their growth forecasts in response to stock prices. Such behavior could reflect a cynical attempt to justify current stock prices or the sincere efforts of Bayesian analysts trying to incorporate others' information reflected in stock prices; either way, if pervasive, this would cause these regressions to be plagued by simultaneity bias.

Given our relatively short time series and the degree of autocorrelation in long-term growth forecasts, simple time series tests of exogeneity are not likely to be very convincing. ${ }^{25}$ Still, some indication of earnings forecast exogeneity might be had by examining whether the estimated errors from our valuation model have substantially greater ability to predict stock price changes than to predict earnings forecast changes. In particular, consider the parsimonious errorcorrection model of stock price changes in equation (9):

$$
\begin{aligned}
& \Delta \log P=0.02+8.93 \cdot \Delta g_{L T}+0.26 \cdot \Delta E-4.26 \cdot \Delta R-0.45 \cdot \text { error }_{t-1}, \quad A d j R^{2}=0.25 \\
& \begin{array}{llll}
(1.86) \quad(2.55) \quad(0.73) \quad(3.61) \quad(1.96)
\end{array}
\end{aligned}
$$

The variable error $_{t-1}$ is the lagged regression error from specification (5) in table 3, our gauge of the (beginning-of-period) deviation between the stock price and its conditional expected value. The other explanatory variables are the contemporaneous quarterly changes in the long-term growth forecast, the log of expected 12-month ahead earnings, and the 30-year bond yield, all in nominal terms. T-statistics shown under the coefficient estimates are based on robust standard errors (Newey-West).

As can be seen, the error-correction term and change in long-term growth are both significant at the 5 percent level; and, together with the interest rate variable, they explain 25

\footnotetext{
${ }^{25}$ What is more, to the extent that forecasts are updated after a slight lag, even if forecasts were truly exogenous with respect to prices, under rational expectations market prices could still cause analyst forecasts in a Granger sense.
} 
percent of the variation in price changes. To gauge the marginal contribution of the long-term growth forecast, this equation was re-estimated with two changes: $\Delta g_{L T}$ was excluded and the lagged error was extracted from a P/E ratio regression that excluded long-term growth. The adjusted R-squared drops to 0.15 in this version, a substantial fall-off from the result in (9).

To gauge the reverse causation, that is, the influence of stock prices on growth forecasts, we estimate a similar regression but with long-term growth (scaled by 100) as the dependent variable:

$$
\begin{aligned}
\Delta g_{L T} \cdot 100= & 0.01+0.57 \cdot \Delta \log P+0.84 \cdot \Delta E-2.74 \cdot \Delta R-0.36 \cdot \text { error }_{t-1}, \text { Adj } R^{2}=0.02 \\
& (0.34)(1.52) \\
(0.81) & (0.74)
\end{aligned}
$$

In this case, the adjusted R-squared is only 0.02 , suggesting that little variation in analysts' longterm growth forecast is explained by stock price changes or the lagged valuation error. Price has a small positive effect, significant only at the 0.13 level. More importantly, the error-correction term has no effect on growth forecasts. Taken together, (9) and (10) thus provide some support for adopting the customary working assumption that analysts' long-term growth forecasts are exogenous with respect to equity prices.

\section{A direct test of inflation's effect on the equity premium}

The evidence on the validity of the model and its application to the survey data provide reasonable support for using the model to construct an explicit ex ante measure of expected longrun stock returns. I construct such a measure of expected real stock returns as follows:

$$
R=(1-\rho)\left[\log \frac{E P S_{0}}{P}+g_{1}+\rho g_{2}+\left(\sum_{j=3}^{12} \rho^{j-1}\right) g_{L T}+\alpha \log \left(\text { payout }_{0}\right)\right]+C
$$

where $\rho=0.96$ and $\alpha=0.15$. As in the regression analysis, the $g$ 's are converted into real growth forecasts by subtracting inflation expectations. To be roughly consistent with the size of the coefficient estimates on $\mathrm{g}_{\mathrm{LT}}$ in the PE ratio regressions (tables 2,3), the long-term growth forecast 
is treated as a forecast for a 10-year period, from year 3 to year $12 .{ }^{26}$ The flip side of this assumption is that expected real earnings growth beyond year 12 is assumed to be constant, or at least stationary.

The constant $C$ is unobservable and influenced by three factors: (i) expected real growth in the out years, (ii) the bias investors impute to analyst earnings forecasts, and (iii) the expected long-run dividend payout rate. Thus, expression (11) only allows us to gauge the relative level of expected returns over time. For purpose of illustration, the estimates are arbitrarily anchored by assuming the expected real return on equity equaled 7 percent in February 1989.

The resulting estimates of expected long-run real equity returns are plotted in Figure 5; and shown alongside is the expected real yield on the 30-year Treasury bond. (Note that the scale for the bond yield-on the left side-is the same as that for the expected equity returns, only shifted up two points to facilitate visual comparison.) The estimates imply that expected real equity returns in early 2001 were about 1 percentage points lower than in 1989, and nearly 3 percentage points lower than in $1984 .{ }^{27}$ These estimates thus suggest that the downward post-war trend of required equity returns identified by Blanchard (1993) has yet to abate. Perhaps the more striking aspect of figure 5 is the apparent positive correlation between the required return on equity and the expected real yield on the 30-year bond, at least until 1998. This relationship contrasts with Blanchard's other main conclusion--that the real return required on Treasury bonds was negatively related to the required return on equity. This disparity might owe to a shift in behavior around the early 1980s; but methodological differences--my use of survey-based expectations--is also likely to be an important factor.

The relationship between the expected return on equity, bond yields, and inflation expectations are summarized by a few simple regressions in Table 4. The first two columns

${ }^{26}$ This assumed horizon would be consistent with a coefficient of 8.34 in the PE regressions. Admittedly, this approach to choosing a horizon is somewhat circular; but this section is not thought of as generating inferences on the equity premium that are independent of earlier results. In any case, changing the assumed horizon by a few years has no material affect on the conclusions to follow.

${ }^{27}$ Of course, given the decline in expected long-run inflation, expected nominal returns on stocks have declined much more than expected real returns. 


\section{Long-Run Expected Return: S\&P 500 vs. 30-year Bond}

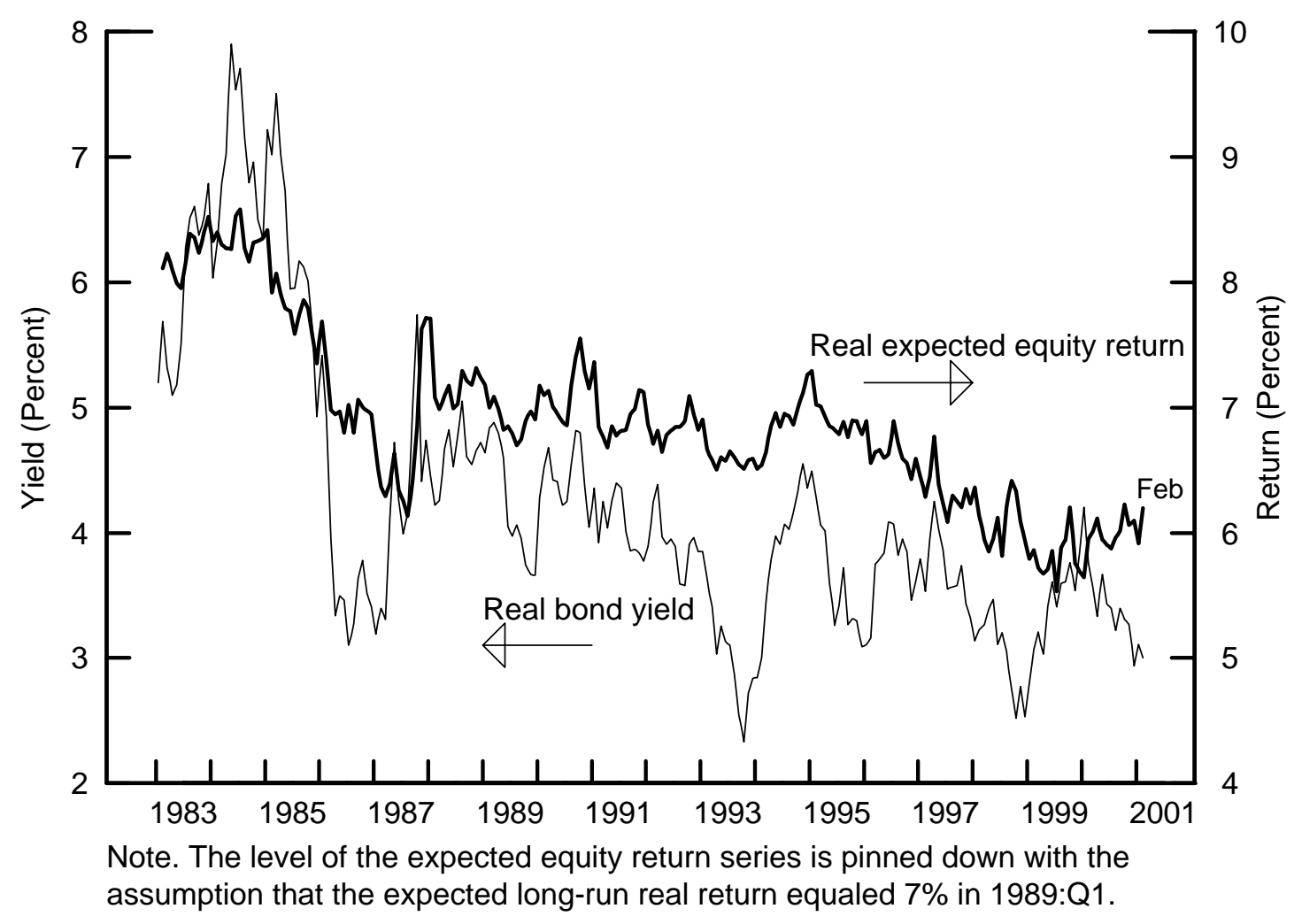


show results of regressions where the dependent variable is the expected long-run real return on the S\&P 500. The first regression measures the univariate relationship between expected real stock returns and expected long-term inflation. The coefficient estimate of 0.66 suggests that a 1 percentage point rise in expected long-term inflation raises the expected long-run real return on equity by two-thirds of a percentage point. The second column considers a multivariate model of expected equity returns, adding the real 30-year Treasury bond yield, the default premium (AAABAA yield spread), and the term premium on Treasuries (the spread between the 30-year and 3month Treasury yields) as explanatory variables. Whereas the bond yield helps explain expected equity returns, its coefficient is far from one, and the latter two regressors are not significant,.

In the third regression, the dependent variable is the expected long-run return premium on equity, defined as the expected real return on equity less the expected real yield on the Treasury bond. The results strongly suggest that the expected return premium is independent of the default and term premia. Perhaps most interesting, though, is the finding that the return premium is unrelated to expected inflation, consistent with the results of the P/E ratio regressions. This finding suggests that, at least over the last two decades, expected inflation's effect on the return required on long-term bonds is similar to the effect on required equity returns. ${ }^{28}$ This conjecture is verified by the last column of Table 4, which shows the result from regressing the real longterm bond yield on expected inflation. The coefficient of 0.75 suggests that a 1 point rise in expected long-run inflation is accompanied by a $3 / 4$ point rise in long-term real yields. ${ }^{29}$

\section{Summary, Interpretation, and Conclusion}

Over the last several decades, equity valuations, as measured by price-earnings ratios, have exhibited a strong negative relation with both actual and expected inflation, a regularity that

\footnotetext{
${ }^{28}$ Summers (1983) argues that bond yields should increase by more than expected inflation. However, his empirical analysis of bond yields and inflation over a variety of periods, the most recent being 1954-1979, suggested that bond yields tend to change by less than changes in expected inflation. My analysis differs in that it uses survey data to measure expected inflation; moreover, the time period analyzed above begins about where Summers' sample period ends.

${ }^{29}$ This suggests that the inflation-hedging benefits of inflation-indexed bonds may be even stronger than intimated by Campbell and Viceira (2001).
} 
cannot be explained by inflation-induced distortions to accounting earnings. According to the present discounted value model, this implies that high inflation presages either high long-run real equity returns or low long-run real earnings growth (holding constant the path of dividend payout rates). My empirical analysis provides evidence to suggest that both factors are at play. Market expectations of real earnings growth, particularly longer-term growth, are negatively related to expected inflation. But even after controlling for these earnings forecasts, equity valuations (PE ratios) are negatively affected by expected inflation, suggesting that inflation also increases the required long-run return on stocks. However, most, if not all, of the inflation-related component in expected stock returns is also in real bond yields. Thus, during the period analyzed in this study, the expected equity risk premium over long-term Treasury bonds appears to be uncorrelated with expected inflation.

One plausible explanation for the positive effect of expected inflation on required real stock and bond returns is an inflation-induced distortion to real effective tax rates on personal investment income [e.g., Feldstein (1980b)]. Because investors pay taxes on their nominal capital income from both stocks and bonds-both the real return as well as the component that compensates investors for depreciation of principal-inflation reduces after-tax real returns; thus, investors are likely to respond by demanding higher real pretax returns.

One question raised but not answered by our findings is why higher long-run inflation expectations are associated with forecasts of lower growth in real--not to mention nominal-earnings. One possibility, of course, is that increases in inflation, even modest increases-result in resource mis-allocation, lower productivity, and slower growth in economic activity. Another possibility that must be given some consideration, even if distasteful to economists, is that investor perceptions may be distorted by inflation.

In their controversial analysis of inflation and equity valuation, Modigliani and Cohn (1979) documented a similar negative relationship between the PE ratio and inflation. While they acknowledged the logical possibility that such a relation could reflect an inflation-related risk premium on stocks relative to bonds, they argued that the magnitude of the effect was difficult to rationalize. The more plausible explanation, they argued, is that investors are plagued by a form of money illusion; in particular, "investors capitalize equity earnings at a rate that parallels the nominal interest rate on bonds, rather than the economically correct real rate--the 
nominal rate less the inflation premium."

But the Modigliani-Cohn analysis assumes that long-run real earnings growth expectations are essentially constant, and imposes some very specific assumptions on the structure of near-term earnings forecasts as well. In particular, their valuation model assumes that investors capitalize a measure of recent profits, adjusted for the current state of the business cycle (and accounting distortions), a measure they call "long-term profit". Thus, their study abstracts from a major piece of our explanation--that real earnings growth forecasts are negatively related to inflation.

Nonetheless, in an important sense, the Modigliani-Cohn hypothesis, that equity prices are distorted by money illusion, could well have been close to the mark. Rather than inappropriately discounting real earnings with a nominal interest rate, it could be that investors use a nominal interest rate to discount expected nominal earnings, where those nominal earnings forecasts are themselves contaminated by money illusion; that is, they might fail to "rationally" incorporate inflation expectations.

Analysts' forecasts of individual firms' earnings--figures that are always discussed in nominal terms--most commonly appear to be anchored in nominal sales growth projections that are extrapolated from recent historical trends. If analysts fail to make adjustments to those trends in response to shifts in the expected long-term inflation rate, then increases in inflation will have the effect of reducing implicit forecasts of real earnings growth. Indeed, Ritter and Warr (1999) show that some recent and relatively sophisticated applications of accounting earnings-based valuation models (e.g., Lee, Myers and Swaminathan (1998)) make no allowance for inflation in their assumptions on long-horizon nominal earnings trajectories. Moreover, they show that the ability of such models' to explain valuations deteriorates when an adjustment for inflation is incorporated into long-horizon residual profit forecasts.

Similarly, few practitioners seem to perceive much benefit from analyzing accounting data and earnings forecasts in real, or inflation-adjusted, terms. One explanation for this might be that the results of simple empirical analyses, such as in Keon (1999), contradict the classical economic presumption that higher inflation translates into higher nominal profit, at least over the short and medium run. In any case, an examination of the determinants of earnings forecasts and their relation to expected inflation should constitute an informative direction for future research. 


\section{Appendix: Earnings Measurement Error}

To examine the issue of measurement error, let $\boldsymbol{Q}_{t} \equiv \boldsymbol{E P S} / \boldsymbol{E P S}_{t}^{a}$, where $\boldsymbol{E P S}_{t}{ }^{a}$ denotes book accounting earnings and $\boldsymbol{E P S _ { t }}$ denotes economic earnings. The variable $\boldsymbol{Q}_{t}$ is meant to represent the "quality" of reported earnings. In an inflationary environment, book accounting earnings are generally thought to overstate true earnings; that is, $\mathrm{Q}<1$. Define the following :

$$
g^{a} \equiv \Delta \log \left(E P S^{a}\right), \quad \phi^{a} \equiv \frac{\log (\text { dividend })}{\log \left(E P S^{a}\right)} .
$$

To show that equation (1) also holds in terms of accounting earnings $\operatorname{EPS}^{\text {a }}$; let $q \equiv \log (Q)$, and substitute $\log \left(E P S^{a}\right)+q$ for $\log (E P S)$ in (1). Doing so yields:

$$
\log \frac{E P S_{t}^{a}}{P_{t}}+q_{t}=E_{t}\left[\sum_{j=1}^{\infty} \rho^{j-1} r_{t+j}-\sum_{j=1}^{\infty} \rho^{j-1}\left(g_{t+j}^{a}+\Delta q_{t+j}\right)-(1-\rho) \sum_{j=1}^{\infty} \rho^{j-1}\left(\phi_{t+j}^{a}-q_{t+j}\right)\right]
$$

But it is straightforward to confirm that the right-hand side terms involving $q$ 's sum up to $q_{t}$, the left-hand-side term; that is,

$$
\text { - } q_{t}-E_{t} \sum_{j=1}^{\infty} \rho^{j-1} \Delta q_{t+j}+(1-\rho) E \sum_{j=1}^{\infty} \rho^{j-1} q_{t+j}=0
$$

Thus, in principle, using accounting earnings does not bias the implied estimate of longhorizon returns. 
References

Bakshi, G. S., and Z. Chen, "Inflation, asset prices, and the term structure if interest rates in monetary economies," Review of Financial Studies, 9 (Spring 1996), 241-276.

Barnes, Michelle, John H. Boyd, and Bruce D. Smith, "Inflation and Asset Returns," European Economic Review 43 (1999), 737-754.

Bernard, Victor L., "Unanticipated inflation and the value of the firm," Journal of Financial Economics 15 (1986), 285-321.

Blanchard, Olivier J., "Movements in the equity premium," Brookings Papers on Economic Activity (1993, no. 2), 75-138.

Bodie, Z., "Common stocks as a hedge against inflation," Journal of Finance, 31 (1976), 459470 .

Boudoukh, Jacob, M. Richardson, "Stock returns and inflation: A long horizon perspective," American Economic Review, 83 (December 1993), 1346-1355.

Boudoukh, Jacob, Matthew Richardson and Robert F. Whitelaw, "Industry returns and the fisher effect," Journal of Finance 49 (December 1994), 1595-1614.

Brown, Lawrence D., "Earnings Forecasting Research: Implications for Capital Markets Research," International Journal of Forecasting 9 (1993), 337.

Campbell, J., 1998, “Asset prices, consumption, and the business cycle,” in John G. Taylor and Michael Woodford (eds), Handbook of macroeconomics, Vol. 1 (Amsterdam: North-Holland, 1999), 1231-1303.

Campbell, John Y. and John Ammer, "What moves the stock and bond markets? A variance decomposition for long-term asset returns," Journal of Finance 48 (March 1993), 3-37.

Campbell, J.Y., A.W. Lo and A.C. MacKinlay, The Econometrics of Financial Markets, 1997 (Princeton: Princeton University Press), 302-304.

Campbell, John Y. and R. Shiller,"Stock prices, earnings, and expected dividends," Journal of Finance 43 (July 1988), 661-671.

Campbell, John Y. and R. Shiller,"The dividend-price ratio and expectations of future dividends and discount factors," Review of Financial Studies, 1 (1989), 195-228.

Campbell, John Y. and Luis M. Viceira, "Who should buy long-term bonds?" American Economic Review 91 (March 2001), 99-127. 
Chen, Nai-Fu, "Financial Investment Opportunities and the Macroeconomy," Journal of Finance 46 (1991), 529-554.

Claus, James and Jacob Thomas, "The Equity Risk Premium is much lower than you think it is: empirical estimates from a new approach," mimeo, Columbia Business School (1998).

De Bondt, W. F.M., Earnings Forecasts and Share Price Reversals, Charlottesville, Virginia: The Research Foundation of The Institute of Chartered Financial Analysis, 1992.

Dechow, P.M. and R.G. Sloan, "Returns to contrarian investment strategies: Tests of naive expectations hypotheses," Journal of Financial Economics 43 (1997), 4-27.

Fama, E., "Stock Returns, real activity, inflation, and money," American Economic Review 71 (1981), 545-565.

Fama, E., and K. French, "Business conditions and expected returns on stocks and bonds ," Journal of Financial Economics 25 (1989), 23-49.

Fama, E. F. and G. W. Schwert, "Asset Returns and Inflation,” Journal of Financial Economics, 5 (1977), 115-146.

Feldstein, M., "Inflation, tax rules and the stock market," Journal of Monetary Economics 6 (1980a), 309-331.

Feldstein, M., "Inflation and the stock market," American Economic Review 70 (1980b), 839-847.

Feldstein, M. and L. Summers, "Effects of inflation oon the taxation of capital income in the corporate sector," National Tax Journal 32 (1979), 445-470.

Fisher, Irving,"The theory of interest," (New York: McMillan, 1930).

Frankel, Richard and Charles M.C. Lee, "Accounting valuation, market expectation, and crosssectional stock returns," Journal of Accounting and Economics, 25 (1998), 283-319.

French, K., R. Ruback, and G.W. Schwert,"Effects of nominal contracting on stock returns," Journal of Political Economy 91 (1983), 70-96.

Froot, Kenneth A., "New Hope for the Expectations Hypothesis of the Term Structure of Interest Rates," Journal of Finance 44 (1989), 283-306.

von Furstenberg, G., and Burton Malkiel, "Financial Analysis in an Inflationary Environment," Journal of Finance 32 (1977), 575-588.

Geske, Robert, and Richard Roll,“The fiscal and monetary linkage between stock returns and inflation,” Journal of Finance 38 (1983), 1-33. 
Hansen, L. and R. Jagannathan, "Restrictions on Intertemporal Marginal Rates of Substitution Implied by Asset Returns," Journal of Political Economy, 99 (1991), 225-262.

Hess, Patrick J. and Bong-Soo Lee, "Stock Returns and Inflation with Supply and Demand Disturbances," The Review of Financial Studies, 12 (1999, no. 5) pp. 1203-18.

Jensen, G., J. Mercer, and R. Johnson, "Business Conditions, monetary policy, and expected security returns," Journal of Financial Economics 40 (1996), 213-237.

Kaul, G.,"Stock returns and inflation: The role of the monetary sector," Journal of Financial Economics 18 (1987), 253-276.

Keim, Donald B. and Robert F. Stambaugh, "Predicting returns in the stock and bond markets," Journal of Financial Economics, 17 (1986), 357-390.

Keon, Edward, "Long-term Equity Returns," Prudential Securities Quantitative Research, November 11, 1999.

Lamont, Owen, "Earnings and Expected Returns," The Journal of Finance 53 (October 1998), 1563-1587.

La Porta, R., "Expectations and the cross-section of returns," Journal of Finance 51 (December 1996), 1715-1742.

Lee, Charles M.C., James Myers, and Bhaskaran Swaminathan, "What is the intrinsic value of the Dow?" Journal of Finance, 54 (1999), 1693-1741.

Lintner, J., "Inflation and security return,”Journal of Finance, 30 (1975), 259-80.

Liu, Jing and Jacob Thomas, "Stock Returns and Accounting Earnings," working paper, Columbia Business School (1999).

Marshall, D., "Inflation and asset return in a monetary economy," Journal of Finance, 47 (1992), 1315-1342.

Modigliani, Franco, and R.A. Cohn, "Inflation and the stock market," Financial Analyst Journal 35 (1979), 24-44.

Nelson, William R., "The Aggregate Change in Shares and the Level of Stock Prices," Finance and Economic Discussion Series no. 1999-08, Federal Reserve Board (1999).

Patelis, A.D., "Stock return predictability and the role of monetary policy," Journal of Finance 52 (1997), 1951-1972.

Pearce, D., and V. Roley, "Firm characteristics, unanticipated inflation, and stock returns," 
Journal of Finance 43 (1998), 965-981.

Rajan, R. and H. Servaes, "Analyst following of initial public offererings," Journal of Finance, 51 (June 1997), 507-529.

Ritter, Jay R. and Richard S. Warr, "The Decline in Inflation and the Bull Market of 1982 to 1999, forthcoming, Journal of Financial and Quantitative Analysis (April 2001).

Rouwenhorst, K. Geert, “Asset Pricing Implications of Equilibrium Business Cycles,” in Frontiers of Business Cycle Research, Thomas F. Cooley, ed, (Princeton, New Jersey: Princeton University Press, 1995), pp. 294-330.

Scanlon, Martha S., "Postwar trends in corporate rates of return," in Public Policy and Capital Formation: A study by the Federal Reserve System (Washington D.C., Board of Governors of the Federal Reserve, 1981).

Shiller, R., and A. Beltratti, "Stock prices and bond yields," Journal of Monetary Economics 30 (1992), 25-46.

Shoven, J., and J. Bulow, "Inflation accounting and nonfinancial corporate accounting: financial assets and liabilities," Brookings Papers on Economic Activity (1976, no 3).

Stulz, R., “Asset pricing and expected inflation,” Journal of Finance 41 (1986), 209-223.

Summers, L. "Inflation and the valuation of corporate equities," NBER working paper (1981).

Summers, L., "The nonadjustment of nominal interest rates: A study of the Fisher effect" in J. Tobin, ed., Macroeconomics, Prices, and Quantities (Washington, D.C.: Brookings Institution, 1983) 201-224.

Thorbecke, W., “On stock market returns and monetary policy,” Journal of Finance 52 (1997), 635-654. 
Table 1

Pearson Correlations of Quarterly Values

\begin{tabular}{|c|c|c|c|c|c|c|c|c|c|}
\hline & $\log \mathrm{P} / \mathrm{E}_{0}$ & $\begin{array}{c}\log \\
\text { payout }\end{array}$ & growth(1) & growth(2) & $\begin{array}{l}\text { long term } \\
\text { growth }\end{array}$ & $\begin{array}{l}\text { 10-yr. } \\
\text { inflation }\end{array}$ & $\begin{array}{l}\text { 4-qtr. } \\
\text { inflation }\end{array}$ & $\begin{array}{l}30-y r \\
\text { bond } \\
\text { yield }\end{array}$ & $\begin{array}{l}\text { default } \\
\text { premium }\end{array}$ \\
\hline log payout & $-0.59 * *$ & & & & & & & & \\
\hline growth(1) & $-0.27 *$ & $0.66^{* *}$ & & & & & & & \\
\hline growth(2) & 0.06 & $0.48 * *$ & $0.51 * *$ & & & & & & \\
\hline $\begin{array}{l}\text { long term } \\
\text { growth }\end{array}$ & $0.77 * *$ & $-0.79 * *$ & $-0.35^{* *}$ & -0.09 & & & & & \\
\hline $\begin{array}{c}10-y r \\
\text { inflation }\end{array}$ & $-0.89 * *$ & $0.73 * *$ & $0.53 * *$ & $0.25^{*}$ & $-0.68 * *$ & & & & \\
\hline $\begin{array}{c}\text { 4-qtr } \\
\text { inflation }\end{array}$ & $-0.88^{* *}$ & $0.59 * *$ & $0.37 * *$ & 0.06 & $-0.68 * *$ & $0.92 * *$ & & & \\
\hline $\begin{array}{c}\text { 30-yr bond } \\
\text { yield }\end{array}$ & $-0.87 * *$ & $0.54 * *$ & $0.45^{* *}$ & 0.14 & $-0.51 * *$ & $0.93 * *$ & $0.87 * *$ & & \\
\hline $\begin{array}{c}\text { default } \\
\text { premium }\end{array}$ & $-0.65^{* *}$ & $0.52 * *$ & $0.44 * *$ & 0.14 & $-0.38 * *$ & $0.78 * *$ & $0.67 * *$ & $0.75 * *$ & \\
\hline $\begin{array}{c}\text { earnings } \\
\text { quality }\end{array}$ & $0.61 * *$ & $-0.62 * *$ & $-0.62 * *$ & $-0.34 * *$ & $0.52 * *$ & $-0.69 * *$ & $-0.47 * *$ & $-0.65^{* *}$ & $-0.65^{* *}$ \\
\hline
\end{tabular}

Correlations marked by ${ }^{*}$ and ${ }^{* *}$ are significant at the $5 \%$ and $1 \%$ level, respectively. 
Table 2

Regressions explaining price-earnings ratio, $\log \mathrm{P} / \mathrm{E}_{0}$

\begin{tabular}{|c|c|c|c|c|c|}
\hline $\begin{array}{c}\text { Explanatory } \\
\text { Variables }\end{array}$ & Theory & (1) & (2) & (3) & (4) \\
\hline growth(1) & 1 & & $\begin{array}{l}0.76^{*} \\
(0.35)\end{array}$ & $\begin{array}{l}0.94^{* *} \\
(0.30)\end{array}$ & \\
\hline growth(2) & 96 & & $\begin{array}{c}0.98^{* *} \\
(0.28)\end{array}$ & $\begin{array}{l}0.75^{* *} \\
(0.26)\end{array}$ & \\
\hline $\begin{array}{l}\text { long-term } \\
\text { growth }\end{array}$ & $>1$ & & $\begin{array}{l}9.39^{* *} \\
(2.03)\end{array}$ & $\begin{array}{c}10.63^{* *} \\
(1.84)\end{array}$ & \\
\hline log payout & $0.04,0.3$ & & $\begin{array}{l}0.34^{*} \\
(0.17)\end{array}$ & $\begin{array}{c}0.23 \\
(0.15)\end{array}$ & $\begin{array}{c}0.22 \\
(0.20)\end{array}$ \\
\hline real bond yield & $\approx-20$ & & & $\begin{array}{l}-6.73^{* *} \\
(1.41)\end{array}$ & $\begin{array}{l}-6.63^{* *} \\
(1.73)\end{array}$ \\
\hline $\begin{array}{l}\text { default } \\
\text { premium }\end{array}$ & - & & & $\begin{array}{l}-0.89 \\
(4.86)\end{array}$ & $\begin{array}{l}-5.06 \\
(5.78)\end{array}$ \\
\hline $10-y r$ inflation & $?$ & $\begin{array}{c}-20.08^{* *} \\
(3.84)\end{array}$ & $\begin{array}{c}-15.23^{* *} \\
(3.23)\end{array}$ & $\begin{array}{l}-5.20 \\
(4.06)\end{array}$ & $\begin{array}{c}-17.10^{* *} \\
3.88\end{array}$ \\
\hline $\begin{array}{l}\text { earnings } \\
\text { quality }\end{array}$ & + & $\begin{array}{c}0.35 \\
(0.63)\end{array}$ & $\begin{array}{c}0.76^{*} \\
(0.37)\end{array}$ & $\begin{array}{c}0.59 \\
(0.32)\end{array}$ & $\begin{array}{c}0.67 \\
(0.65)\end{array}$ \\
\hline$\epsilon_{\mathrm{t}-1}$ & & $\begin{array}{c}0.79^{* *} \\
(0.07)\end{array}$ & $\begin{array}{c}0.36^{* *} \\
(0.12)\end{array}$ & $\begin{array}{c}0.30^{*} \\
(0.12)\end{array}$ & $\begin{array}{l}0.77^{* *} \\
(0.08)\end{array}$ \\
\hline Regression $\mathrm{R}^{2}$ & & 0.35 & 0.88 & 0.90 & 0.50 \\
\hline $\begin{array}{l}\text { Number of } \\
\text { observations }\end{array}$ & & 73 & 73 & 73 & 73 \\
\hline
\end{tabular}

Observations are quarterly, from 1983-2001:Q1. Regressions are estimated using the Yule-Walker method. Standard errors are shown below coefficient estimates, which are marked with * ${ }^{*}{ }^{* *}$ if they are significant at the $5 \%$ or $1 \%$ level, respectively. 
Table 3

Regressions explaining price-earnings ratio, $\log \mathrm{P} / \mathrm{E}_{0}$

\begin{tabular}{|c|c|c|c|c|c|}
\hline $\begin{array}{c}\text { Explanatory } \\
\text { Variables }\end{array}$ & Theory & (5) & (6) & (7) & (8) \\
\hline $\operatorname{growth}(1)$ & 1 & $\begin{array}{l}1.08^{* *} \\
(0.31)\end{array}$ & $\begin{array}{l}0.80^{*} \\
(0.37)\end{array}$ & $\begin{array}{c}0.85^{* *} \\
(0.28)\end{array}$ & $\begin{array}{c}0.84^{* *} \\
(0.31)\end{array}$ \\
\hline $\operatorname{growth}(2)$ & .96 & $\begin{array}{l}(0.91)^{*} \\
(0.39)\end{array}$ & $\begin{array}{r}0.51 \\
(0.49)\end{array}$ & $\begin{array}{l}0.98^{* *} \\
(0.25)\end{array}$ & $\begin{array}{c}0.71^{\text {*** }} \\
(0.26)\end{array}$ \\
\hline $\begin{array}{l}\text { long-term } \\
\text { growth }\end{array}$ & $>1$ & $\begin{array}{l}9.93^{* *} \\
(2.21)\end{array}$ & $\begin{array}{l}11.77^{* *} \\
(2.45)\end{array}$ & $\begin{array}{c}4.00 \\
(2.39)\end{array}$ & $\begin{array}{c}9.60^{* *} \\
(1.83)\end{array}$ \\
\hline $\log$ payout & $0.04, .3$ & $\begin{array}{c}0.17 \\
(0.19)\end{array}$ & $\begin{array}{r}0.39 \\
(0.21)\end{array}$ & $\begin{array}{c}0.24 \\
(0.13)\end{array}$ & $\begin{array}{c}0.22 \\
(0.15)\end{array}$ \\
\hline real bond yield & $\approx-20$ & $\begin{array}{l}-6.62^{* *} \\
(1.18)\end{array}$ & $\begin{array}{l}-6.97^{* *} \\
(1.67)\end{array}$ & $\begin{array}{l}-6.6^{* *} \\
(1.40)\end{array}$ & $\begin{array}{l}-9.02^{* *} \\
(1.16)\end{array}$ \\
\hline $10-y r$ inflation & $?$ & $\begin{array}{l}-6.28^{*} \\
(2.85)\end{array}$ & $\begin{array}{l}-6.81 \\
(3.52)\end{array}$ & $\begin{array}{c}-10.96^{* *} \\
(3.89)\end{array}$ & \\
\hline earnings quality & + & $\begin{array}{c}0.68^{* *} \\
(0.26)\end{array}$ & $\begin{array}{c}0.28 \\
(0.29)\end{array}$ & $\begin{array}{c}0.61^{*} \\
(0.27)\end{array}$ & $\begin{array}{l}0.71^{*} \\
0.31\end{array}$ \\
\hline $\log \left(\mathrm{P} / \mathrm{E}_{\mathrm{o}}\right)_{\mathrm{t}-1}$ & & & $\begin{array}{l}0.38^{* *} \\
(0.11)\end{array}$ & & \\
\hline$\epsilon_{\mathrm{t}-1}$ & & & & $\begin{array}{c}0.10 \\
(0.14)\end{array}$ & $\begin{array}{c}0.23 \\
(0.14)\end{array}$ \\
\hline Regression $\mathrm{R}^{2}$ & & 0.96 & 0.97 & 0.91 & 0.86 \\
\hline $\begin{array}{l}\text { Number of } \\
\text { observations }\end{array}$ & & 73 & 73 & 56 & 56 \\
\hline
\end{tabular}

Observations are quarterly, from 1983-2001:Q1 in (6), (7) and 1983-1996 in (8), (9). Standard errors are shown below coefficient estimates, which are marked with ${ }^{*}$ or ${ }^{* *}$ if significant at the $5 \%$ or $1 \%$ level, respectively. In (5) and (6), standard errors are calculated using the Newey-West method. Regressions (7) and (8) with AR(1) terms are estimated using the Yule-Walker method. 
Table 4

\section{Explaining long-run expected returns}

\begin{tabular}{|c|c|c|c|c|}
\hline \multirow[b]{2}{*}{$\begin{array}{c}\text { Explanatory } \\
\text { Variables }\end{array}$} & \multicolumn{4}{|c|}{ Dependent Variable: } \\
\hline & Expectec & ity return & $\begin{array}{l}\text { Expected return } \\
\text { premium }\end{array}$ & $\begin{array}{l}\text { Expected real } \\
\text { bond yield }\end{array}$ \\
\hline real bond yield & & $\begin{array}{l}0.25^{* *} \\
(0.05)\end{array}$ & & \\
\hline 10-yr inflation & $\begin{array}{l}0.66^{* *} \\
0.07\end{array}$ & $\begin{array}{l}0.40^{* *} \\
(0.09)\end{array}$ & $\begin{array}{l}-0.28 \\
(0.18)\end{array}$ & $\begin{array}{l}0.75^{* *} \\
(0.18)\end{array}$ \\
\hline default premium & & $\begin{array}{c}0.08 \\
(0.18)\end{array}$ & $\begin{array}{c}0.09 \\
(0.36)\end{array}$ & \\
\hline term premium & & $\begin{array}{c}0.03 \\
(0.05)\end{array}$ & $\begin{array}{c}0.06 \\
(0.11)\end{array}$ & \\
\hline$\epsilon_{\mathrm{t}-1}$ & $\begin{array}{l}0.50^{* *} \\
(0.10)\end{array}$ & $\begin{array}{c}0.40 \\
(0.11)\end{array}$ & $\begin{array}{l}0.60^{* *} \\
0.10\end{array}$ & $\begin{array}{l}0.69^{* *} \\
(0.09)\end{array}$ \\
\hline Regression $\mathrm{R}^{2}$ & 0.56 & 0.74 & 0.05 & 0.20 \\
\hline
\end{tabular}

Observations are quarterly, 1983-1998. Regressions are estimated using the Yule-Walker method. Standard errors are shown below coefficient estimates, which are marked with ${ }^{*}$ or ${ }^{* *}$ if significant at the $5 \%$ or $1 \%$ level, respectively. 